\title{
The Reaction of a Nitro-Capped Cobalt(III) Cage Complex with Base: the Crystal Structure of a Contracted Cage Complex, and the Mechanism of its Formation*
}

\author{
Rodney J. Geue, ${ }^{\mathrm{A}}$ Peter Osvath, ${ }^{\mathrm{A}}$ Alan M. Sargeson, ${ }^{\mathrm{A}}$ \\ K. Ravindra Acharya, ${ }^{\mathrm{B}}$ Sahina Begum Noor ${ }^{\mathrm{C}}$ Taylor N. Guru Row ${ }^{\mathrm{B}}$ \\ and Kailasam Venkatesan ${ }^{\mathrm{B}}$
}

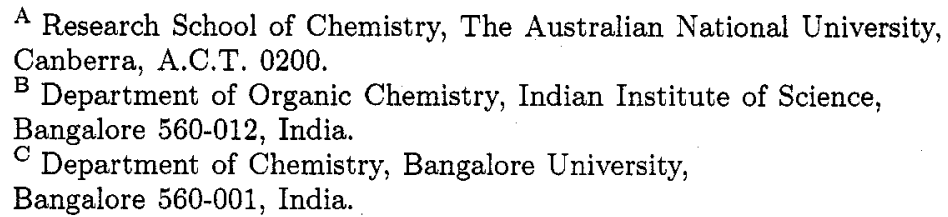

\section{Abstract}

The synthesis, properties and crystal structure of the cage complex (1-hydroxy-8-methyl$3,6,10,13,15,18$-hexaazabicyclo[6.6.5]nonadecane)cobalt(III) chloride hydrate ([Co(Me,OHabsar) $] \mathrm{Cl}_{3} \cdot \mathrm{H}_{2} \mathrm{O}$ ) are reported. The mechanism of the formation of this contracted cavity cage from a nitro-capped hexaazabicycloicosane type cage has been investigated. Treatment of (1methyl-8-nitro-3,6,10,13,16,19-hexaazabicyclo[6.6.6]icosane) cobalt(III) chloride ([Co( $\mathrm{Me}, \mathrm{NO}_{2}-$ $\mathrm{sar})]^{3+}$ ) with excess base in aqueous solution leads initially to rapid $\left(t_{1 / 2}<1 \mathrm{~ms}\right)$ and reversible deprotonation of one coordinated secondary amine. This species undergoes a retro-Mannich type reaction and imine hydrolysis $\left(t_{1 / 2} \approx 90 \mathrm{~s}\right)$. Quenching the reaction with acid gives rise to a pair of isomeric intermediate species which have been isolated and characterized. They have a pendant arm macrocyclic structure, resulting from the loss of a methylene unit from one of the arms of the cap. Heating either isomer in aqueous solution gives the new cage compound with the contracted cap. It is postulated that this occurs through a Nef reaction, resulting in the formation of a ketone which then condenses with the coordinated primary amine. A comparison with the corresponding bicycloicosane analogue indicates a reduced chromophoric cavity size for the contracted cage. The reduction potential of the cobalt(III)/cobalt(II) couple is $170 \mathrm{mV}$ more negative for the smaller cage, and, in the electronic spectrum of the cobalt(III) complex, the $d-d$ transitions are both shifted to higher energy, corresponding to a stronger ligand field.

\section{Introduction}

The syntheses and properties of a large range of cobalt complexes encapsulated by a cage ligand of the 'sar' type (1) have been reported, and their unusual properties have been documented. ${ }^{1}$ Various modifications to this basic cage have since been investigated, to determine their effect on the encapsulated metal.

* Dedicated to the memory of Graeme Searle, a good friend and colleague, and devoted chemist and teacher, with many sterling contributions to the chemical literature.

${ }^{1}$.Sargeson, A. M., Pure Appl. Chem., 1986, 58, 1511, and references cited therein. 
The apical substituents have been varied, ${ }^{2}$ as have the donor groups ${ }^{3-5}$ and the bridgehead atoms, ${ }^{6,7}$ Also, the effect of fixing conformational configurations through $C$-substituted peripheral alkyl groups has been explored in detail. ${ }^{8-10}$ Differences in the apical substituent change the electronic properties (reduction potential, electron self exchange rate) to a modest extent, whereas changing the conformational geometry has a profound effect on the electronic and spectroscopic properties. As expected, replacing the amine donor groups by thioethers has a marked effect on the electronic properties, electron transfer rates and stability. More recently, symmetrical larger cages based on trimethylene bridging units have been prepared both with $\mathrm{N}_{6}{ }^{11-14}$ and with $\mathrm{S}_{6}{ }^{15}$ donor sets, and these variations have brought about some exceptional new properties for the resulting complexes.

During earlier studies in which cages with different apical substituents were prepared, it was found that diazotization of an apical primary amine led to the formation of an adamantyl type carbocation which captured a variety of nucleophiles. ${ }^{2}$ A number of minor products were also isolated, in which it was apparent that this adamantyl-like carbocation had rearranged in an unexpected manner to give a primary carbocation (presumably to relieve strain in the carbocation and to reduce the electrostatic repulsion between the $\mathrm{Co}^{3+}$ centre and the $\mathrm{C}^{+}$) prior to attack by the nucleophile. This resulted in the formation of a contracted ('absar') cage (2) in which one 'arm' of the cap has lost a methylene unit. ${ }^{1,2,16}$ Similar behaviour has also been noted for the related complexes with an $\mathrm{N}_{3} \mathrm{~S}_{3}$ donor set. ${ }^{4}$

For $\left[\mathrm{Co}\left(\left(\mathrm{NO}_{2}\right)_{2} \text {-sar }\right)\right]^{3+}\left([\mathrm{Co}(1)]^{3+}, \mathrm{X}=\mathrm{Y}=\mathrm{NO}_{2}\right),{ }^{*}$ the enhanced acidity of the coordinated secondary amine hydrogen had previously been noted; ${ }^{2}$ above

* For clarity, throughout this paper the apically substituted derivatives of the two cage types, sar (1) and absar (2), will be abbreviated as X,Y-sar, $X_{2}$-sar (where $X=Y$ ) and $X, Y$-absar.

${ }^{2}$ Geue, R. J., Hambley, T. W., Harrowfield, J. M., Sargeson, A. M., and Snow, M. R., J. Am. Chem. Soc., 1984, 106, 5478; Höhn, A., Geue, R. J., and Sargeson, A. M., J. Chem. Soc., Chem. Commun., 1990, 1473.

${ }^{3}$ Gahan, L. R., Hambley, T. W., Sargeson, A. M., and Snow, M. R., Inorg. Chem., 1982, 21, 2699.

${ }^{4}$ Lay, P. A., Lydon, J., Mau, A. W.-H., Osvath, P., Sargeson, A. M., and Sasse, W. H. F., Aust. J. Chem., 1993, 46, 641 .

${ }^{5}$ Osvath, P., Sargeson, A. M., Skelton, B. W., and White, A. H., J. Chem. Soc., Chem. Commun., 1991, 1036.

${ }^{6}$ Höhn, A., Geue, R. J., Sargeson, A. M., and Willis, A. C., J. Chem. Soc., Chem. Commun., $1989,1644$.

7 Höhn, A., Geue, R. J., Sargeson, A. M., and Willis, A. C., J. Chem. Soc., Chem. Commun., $1989,1648$.

8 Geue, R. J., McCarthy, M. G., and Sargeson, A. M., J. Am. Chem. Soc., 1984, 106, 8282.

${ }^{9}$ Geue, R. J., Hendry, A. J., and Sargeson, A. M., J. Chem. Soc., Chem. Commun., 1989, 1646 .

${ }^{10}$ Hendry, A. J., Ph.D. Thesis, Australian National University, 1986.

11 Geue, R. J., McDonnell, M. B., Mau, A. W.-H., Sargeson, A. M., and Willis, A. C., J. Chem. Soc., Chem. Commun., in press.

12 Geue, R. J., Höhn, A., Ralph, S. F., Sargeson, A. M., and Willis, A. C., unpublished data. ${ }^{13}$ Bygott, A. M. J., Geue, R. J., Ralph, S. F., Sargeson, A. M., and Willis, A. C., unpublished data.

${ }^{14}$ Bygott, A. M. J., Geue, R. J., Haller, K. J., Rae, A. D., Ralph, S. F., and Sargeson, A. M., unpublished data.

15 Osvath, P., and Sargeson, A. M., J. Chem. Soc., Chem. Commun., 1993. 40.

16 Clarke, I. J., Geue, R. J., Engelhardt, L. M., Harrowfield, J. M., Sargeson, A. M., and White, A. H., Aust. J. Chem., 1993, 46, 1485. 


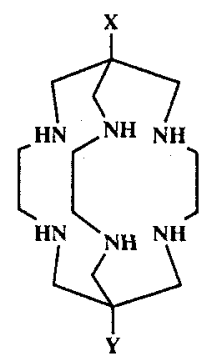

(1)

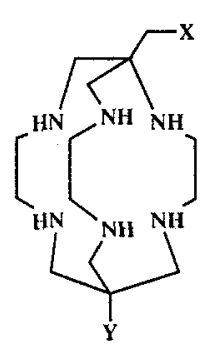

(2)

$\mathrm{pH} 10$, for example, a solution of $\left[\mathrm{Co}\left(\left(\mathrm{NO}_{2}\right)_{2}-\mathrm{sar}\right)\right]^{3+}$ has a characteristic intense purple colour resulting from the presence of a deprotonated coordinated amine. The crystal structure of the complex was determined, and indeed showed the expected shortening of one $\mathrm{Co}-\mathrm{N}$ bond, as well as a slight flattening of the structure around this nitrogen compared with the tetrahedral values of the other coordinated amines. ${ }^{2}$ In more concentrated base, the complex undergoes a complicated set of ring opening reactions, but the $\left[\mathrm{Co}\left(\mathrm{Me}, \mathrm{NO}_{2} \text {-sar }\right)\right]^{3+}$ ion reacts by a somewhat simpler path. The kinetics of its reaction with base and the mechanism of the rearrangement, together with an examination of the properties of the product, are the subject of this article.

\section{Experimental}

\section{General Methods}

All evaporations were carried out at $<20$ Torr with a Büchi rotatory evaporator so that the temperature of the sample did not exceed $25^{\circ} \mathrm{C} .{ }^{1} \mathrm{H}$ and proton-decoupled ${ }^{13} \mathrm{C}$ n.m.r. spectra were recorded with a Varian Gemini $300 \mathrm{MHz}$ Fourier-transform n.m.r. spectrometer, by using 1,4-dioxan as internal reference (the signals for dioxan in $\mathrm{D}_{2} \mathrm{O}$ are taken as $3.74 \mathrm{ppm}$ for ${ }^{1} \mathrm{H}$ n.m.r. and 67.39 ppm for ${ }^{13} \mathrm{C}$ n.m.r. relative to tetramethylsilane). ${ }^{13} \mathrm{C}$ peak multiplicities were assigned by using the APT or DEPT techniques as appropriate. Electronic absorption spectra and kinetic traces were obtained with a Hewlett-Packard $8450 \mathrm{~A}$ u.v./visible spectrophotometer. Electronic spectra of the cobalt(II) complexes $(300-1100 \mathrm{~nm})$ were obtained with a Cary 5 spectrophotometer. Electrochemistry was carried out with a BAS 100 electrochemical analyser, by using $0.2 \mathrm{M}$ aqueous $\mathrm{KCl}$ solution saturated with high-purity argon, a glassy carbon working electrode, a platinum wire auxiliary electrode, and a saturated calomel reference electrode; measurements were made at $22^{\circ} \mathrm{C}$ and the scan rate was varied from 10 to $100 \mathrm{mV} \mathrm{s}^{-1}$ with no effect on the reduction potential. The spectral parameters and reduction potentials are listed in Table 1.

\section{Kinetic Measurements}

Kinetic measurements were performed by using a Hewlett-Packard $8450 \mathrm{~A}$ u.v./visible spectrophotometer in repeat scan mode, or an Applied Photophysics SF $17 \mathrm{MV}$ stopped flow spectrophotometer. For the stopped flow experiments, the ionic strength was held constant $(I=1.0 \mathrm{M})$ with $\mathrm{NaCl}$. The temperature was $25^{\circ} \mathrm{C}$ in all cases.

$\left[\mathrm{Co}\left(\mathrm{Me}, \mathrm{NO}_{2}-\mathrm{sar}\right)\right] \mathrm{Cl}_{3}$

The synthesis was carried out as previously reported, ${ }^{2}$ and the product was recrystallized from aqueous $\mathrm{HCl}$ (Found: $\mathrm{C}, 34.5 ; \mathrm{H}, 6.5 ; \mathrm{Cl}, 20 \cdot 2 ; \mathrm{N}, 18 \cdot 5 . \mathrm{C}_{15} \mathrm{H}_{33} \mathrm{Cl}_{3} \mathrm{CoN}_{7} \mathrm{O}_{2} . \mathrm{H}_{2} \mathrm{O}$ requires $\mathrm{C}, 34 \cdot 2 ; \mathrm{H}, 6 \cdot 7 ; \mathrm{Cl}, 20 \cdot 2 ; \mathrm{N}, 18 \cdot 6 \%) .{ }^{1} \mathrm{H}$ n.m.r. $\delta\left(\mathrm{D}_{2} \mathrm{O}\right): 3 \cdot 9-2 \cdot 4$, complex pattern, 
$\mathrm{CH}_{2} \mathrm{~N}, 24 \mathrm{H} ; 0.93, \mathrm{~s}, \mathrm{CH}_{3}, 3 \mathrm{H}$ (Fig. $\left.1 a\right) .{ }^{13} \mathrm{C}$ n.m.r. $\delta\left(\mathrm{D}_{2} \mathrm{O}\right): 88 \cdot 60, \mathrm{C}_{\mathrm{q}} \mathrm{NO}_{2} ; 55 \cdot 81$, approx. double intensity, $\mathrm{NCH}_{2} \mathrm{CH}_{2} \mathrm{~N} ; 55 \cdot 15, \mathrm{CH}_{2} \mathrm{C}_{\mathrm{q}} \mathrm{CH}_{3} ; 51 \cdot 82, \mathrm{CH}_{2} \mathrm{C}_{\mathrm{q}} \mathrm{NO}_{2} ; 43 \cdot 53, \mathrm{C}_{\mathrm{q}} \mathrm{CH}_{3} ; 20 \cdot 06$, $\mathrm{CH}_{3}$.

Table 1. Spectral and electrochemical properties

\begin{tabular}{|c|c|c|c|c|c|}
\hline \multirow{4}{*}{$\begin{array}{l}\text { Complex } \\
\text { Cobalt(III) } \\
{\left[\mathrm{Co}\left(\mathrm{Me}, \mathrm{NO}_{2} \text {-sar }\right)\right]^{3+}} \\
{\left[\mathrm{Co}\left(\mathrm{Me}, \mathrm{NO}_{2} \text {-sar }-\mathrm{H}^{+}\right)\right]^{2+}} \\
{[\mathrm{CoL}]^{3+\mathrm{C}}}\end{array}$} & \multicolumn{4}{|c|}{$\lambda_{\max }\left(\epsilon_{\max }\right)^{\mathrm{A}}$} & $E^{\circ \prime}(\mathrm{mV})^{\mathrm{B}}$ \\
\hline & & & & & \\
\hline & $345(117)$ & $472(135)$ & & & -264 \\
\hline & $330(790)$ & $476(275)$ & & & - \\
\hline Isomer $A$ & $348(146)$ & $478(143)$ & & & -196 \\
\hline Isomer $B$ & $346(132)$ & $478(137)$ & & & -196 \\
\hline$[\mathrm{Co}(\mathrm{Me}, \mathrm{OH}-\mathrm{absar})]^{3+}$ & $336(172)$ & $458(175)$ & & & -551 \\
\hline$[\mathrm{Co}(\mathrm{Me}, \mathrm{OH}-\mathrm{sar})]^{3+}$ & $344(124)$ & $472(143)$ & & & -385 \\
\hline${\operatorname{Cobalt}(\mathrm{II})^{\mathrm{D}}}$ & ${ }^{4} \mathrm{~T}_{1 \mathrm{~g}}(\mathrm{P})$ & ${ }^{2} \mathrm{~T}_{1 \mathrm{~g}}(\mathrm{P})$ & $\begin{array}{l}{ }^{2} \mathrm{~T}_{1 \mathrm{~g}}(\mathrm{G}) \\
{ }^{2} \mathrm{~T}_{2 g}(\mathrm{G})\end{array}$ & ${ }^{4} \mathrm{~T}_{2 \mathrm{~g}}(\mathrm{~F})$ & \\
\hline$[\mathrm{Co}(\mathrm{Me}, \mathrm{OH}-\mathrm{sar})]^{2+}$ & $458(12)$ & $583(6)$ & $638(\mathrm{sh}, 5)$ & $952(7)$ & \\
\hline$[\mathrm{Co}(\mathrm{Me}, \mathrm{OH}-\mathrm{absar})]^{2+}$ & $467(13)$ & $550(5 \cdot 3)$ & $658(3 \cdot 4)$ & $870(6)$ & \\
\hline$[\mathrm{Co}(\mathrm{Me}-\mathrm{azasar})]^{2+\mathrm{E}}$ & $463(8 \cdot 6)$ & $551(3 \cdot 5)$ & $644(0.9)$ & $921(5 \cdot 5)$ & \\
\hline$[\mathrm{Co}(\mathrm{sep})]^{2+\mathrm{E}}$ & $467(8 \cdot 2)$ & $545(2 \cdot 0)$ & $664(0.8)$ & $910(4 \cdot 9)$ & \\
\hline
\end{tabular}

$\lambda_{\max }$ in $\mathrm{nm}\left(\epsilon_{\max }\right.$ in $\left.\mathrm{dm}^{3} \mathrm{~mol}^{-1} \mathrm{~cm}^{-1}\right)$.

B $v$. s.h.e., $22^{\circ} \mathrm{C}$.

${ }^{\mathrm{C}} \mathrm{L}=$ 6-(4-amino-2-azabutyl)-6-methyl-13-nitro-1,4,8,11-tetraazacyclotetradecane.

D Assignments are based on those of Palmer, R. A., and Yang, M. C.-L., Chem. Phys. Lett., $1975,31,492$.

${ }^{\mathrm{E}}$ Creaser, I. I., Geue, R. J., Harrowfield, J. M., Herlt, A. J., Sargeson, A. M., Snow, M. R., and Springborg, J., J. Am. Chem. Soc., 1982, 104, 6016.

$[\mathrm{Co}(\mathrm{Me}, \mathrm{OH}-\mathrm{sar})] \mathrm{Cl}_{3}$

$\mathrm{NaNO}_{2}(350 \mathrm{mg})$ was added over $30 \mathrm{~min}$ to a stirred solution of $\left[\mathrm{Co}\left(\mathrm{Me}, \mathrm{NH}_{3}-\mathrm{sar}\right)\right]\left(\mathrm{CF}_{3} \mathrm{SO}_{3}\right)_{4}{ }^{2}$ $(4.85 \mathrm{~g})$ in water $(50 \mathrm{ml})$ at $0^{\circ} \mathrm{C}$. Two aliquots of trific acid $(2 \mathrm{M}, 5 \mathrm{ml})$ were added at $30-\mathrm{min}$ intervals. The solution was diluted to 5 litres and loaded onto a column of SP-Sephadex C-25. Elution with $0.1 \mathrm{M} \mathrm{K}_{2} \mathrm{HPO}_{4}$ gave four fractions; the third fraction was loaded onto Dowex 50W-X2 (200-400 mesh) cation exchange resin, washed with water, $1 \mathrm{M} \mathrm{HCl}$, eluted with $4 \mathrm{M}$ $\mathrm{HCl}$, evaporated to dryness, and recrystallized from water/acetone. Yield $60 \% .{ }^{1} \mathrm{H}$ n.m.r. $\delta$ $\left(\mathrm{D}_{2} \mathrm{O}\right): 3 \cdot 4-2 \cdot 4$, complex pattern, $\mathrm{CH}_{2} \mathrm{~N}, 24 \mathrm{H} ; 0.91$, s, $\mathrm{CH}_{3}, 3 \mathrm{H} .{ }^{13} \mathrm{C}$ n.m.r. $\delta\left(\mathrm{D}_{2} \mathrm{O}\right): 73 \cdot 76$, $\mathrm{C}_{\mathrm{q}} \mathrm{OH} ; 55 \cdot 84$, approx. double intensity, $55 \cdot 13,54 \cdot 91, \mathrm{CH}_{2} \mathrm{~N} ; 43 \cdot 14, \mathrm{C}_{\mathrm{q}} \mathrm{CH}_{3} ; 20 \cdot 12, \mathrm{CH}_{3}$. Electronic spectrum in aqueous $\mathrm{HCl}(0.1 \mathrm{M})\left[\lambda_{\max }\right.$ in $\mathrm{nm}\left(\epsilon_{\max }\right.$ in $\left.\left.\mathrm{dm}^{3} \mathrm{~mol}^{-1} \mathrm{~cm}^{-1}\right)\right]: 472$ (143), 344 (124).

$[\mathrm{Co}(\mathrm{Me}, \mathrm{OH}-\mathrm{sar})]^{2+}$

$[\mathrm{Co}(\mathrm{Me}, \mathrm{OH}-\mathrm{sar})]^{2+}$ was prepared by reduction of an argon-saturated aqueous solution of $[\mathrm{Co}(\mathrm{Me}, \mathrm{OH}-\mathrm{sar})]^{3+}$ with zinc dust directly in the spectrophotometer cell. Electronic spectrum in $\mathrm{H}_{2} \mathrm{O}\left[\lambda_{\max }\right.$ in $\mathrm{nm}\left(\epsilon_{\max }\right.$ in $\left.\left.\mathrm{dm}^{3} \mathrm{~mol}^{-1} \mathrm{~cm}^{-1}\right)\right]: 952(7), 638(\mathrm{sh}, 5), 583(6), 458(12)$.

(3) $\left.\mathrm{COO}\left(\mathrm{Me}, \mathrm{NO}_{2}-\mathrm{sar}-\mathrm{H}^{+}\right)\right]^{2+}$

A sample of $\left[\mathrm{Co}\left(\mathrm{Me}_{2} \mathrm{NO}_{2}\right.\right.$-sar $\left.)\right] \mathrm{Cl}_{3}$ was dissolved in $\mathrm{D}_{2} \mathrm{O}$ and 1 equiv. of $\mathrm{NaOD}$ was added. The solution darkened immediately, and the ${ }^{1} \mathrm{H}$ and ${ }^{13} \mathrm{C}$ n.m.r. spectra were recorded; the spectra that were recorded after $90 \mathrm{~min}$ were identical to those of the initial product. ${ }^{1} \mathrm{H}$ n.m.r. $\delta\left(\mathrm{D}_{2} \mathrm{O}+1\right.$ equiv. $\left.\mathrm{NaOD}\right): 3 \cdot 62, \mathrm{~d}, J 14 \mathrm{~Hz}, 3 \mathrm{H} ; 3 \cdot 3-2 \cdot 5$, complex pattern, $\mathrm{CH}_{2} \mathrm{~N}$, $18 \mathrm{H} ; 2 \cdot 38, \mathrm{~d}, J 14 \mathrm{~Hz}, 3 \mathrm{H} ; 0.87, \mathrm{~s}, \mathrm{CH}_{3} .{ }^{13} \mathrm{C}$ n.m.r. $\delta\left(\mathrm{D}_{2} \mathrm{O}+1\right.$ equiv. NaOD $): 90 \cdot 25, \mathrm{C}_{\mathrm{q}} \mathrm{NO}_{2}$; $56 \cdot 51,55 \cdot 75,55 \cdot 66,53 \cdot 01, \mathrm{CH}_{2} \mathrm{~N} ; 42 \cdot 90, \mathrm{C}_{\mathrm{q}} \mathrm{CH}_{3} ; 20 \cdot 33, \mathrm{CH}_{3}$. N.m.r. spectra were acquired 
for solutions of $\left[\mathrm{Co}\left(\mathrm{Me}, \mathrm{NO}_{2} \text {-sar }\right)\right]^{3+}($ c. $0.3 \mathrm{M})$ containing 1 equiv. of $\mathrm{NaOD}$, excess $\mathrm{Na}_{2} \mathrm{CO}_{3}$, and $\mathrm{NaOD}(c .1 \mathrm{M})$ respectively. The peak positions (but not the splitting patterns) were strongly dependent on $\mathrm{pH}$. (See Results and Discussion.) Electronic spectrum in aqueous $\mathrm{NaOH}(0.1 \mathrm{M})\left[\lambda_{\max }\right.$ in $\mathrm{nm}\left(\epsilon_{\max }\right.$ in $\left.\left.\mathrm{dm}^{3} \mathrm{~mol}^{-1} \mathrm{~cm}^{-1}\right)\right]$ : $476(275), 330(790)$.

(5) $\left[\mathrm{Co}\left(6-\mathrm{Me}, 13-\mathrm{NO}_{2}, 6-\mathrm{CH}_{2} \mathrm{NHCH}_{2} \mathrm{CH}_{2} \mathrm{NH}_{2}-[14] \mathrm{aneN} \mathrm{N}_{4}\right)\right] \mathrm{Cl}_{3} \cdot 3 \mathrm{H}_{2} \mathrm{O}$ (Isomer A), (6-(4-Amino-2-azabutyl)-6-methyl-13-nitro-1,4,8,11-tetraazacyclotetradecane) cobalt(III) Chloride Trihydrate

A solution of $\mathrm{NaOH}(6.1 \mathrm{~g})$ in $30 \mathrm{ml}$ of water was added to a solution of [Co(Me, $\mathrm{NO}_{2}$-sar) $) \mathrm{Cl}_{3}$ $(3.14 \mathrm{~g})$ in $50 \mathrm{ml}$ of water. The mixture immediately darkened. After stirring for $15 \mathrm{~min}$ at $20^{\circ} \mathrm{C}$, the mixture was quenched with $11.7 \mathrm{M} \mathrm{HCl}(15 \mathrm{ml}$; final $\mathrm{pH}<1)$, and then diluted to c. $500 \mathrm{ml}$ with dilute $\mathrm{HCl}(0.2 \mathrm{M})$. It was sorbed onto a column of Dowex $50 \mathrm{~W}$-X2 cation exchange resin. The column was washed with $1 \mathrm{M} \mathrm{HCl}$, and then eluted with $4 \mathrm{M} \mathrm{HCl}$. The eluate containing the cationic complexes was evaporated to dryness, and the residue was dissolved in water, loaded onto a column of SP-Sephadex, and eluted with $0.05 \mathrm{M} \mathrm{K}_{2} \mathrm{SO}_{4}$. A band corresponding to starting material was eluted first, and the diffuse band that followed was collected, made basic with $\mathrm{Na}_{2} \mathrm{CO}_{3}$, reacidified, and loaded onto Dowex 50W-X2 cation exchange resin. The column was washed with $1 \mathrm{M} \mathrm{HCl}$, and then eluted with $4 \mathrm{M} \mathrm{HCl}$. The eluate was evaporated to dryness, to give the product.

A sample was recrystallized from methanol/absolute ethanol (Found: C. 31.0; H, 7.1; N, 17.4. $\mathrm{C}_{14} \mathrm{H}_{33} \mathrm{Cl}_{3} \mathrm{CoN}_{7} \mathrm{O}_{2} .3 \mathrm{H}_{2} \mathrm{O}$ requires $\mathrm{C}, 30 \cdot 5 ; \mathrm{H}, 7 \cdot 1 ; \mathrm{N}, 17.8 \%$ ). Electronic spectrum in aqueous $\mathrm{HCl}(0.1 \mathrm{M})\left[\lambda_{\max }\right.$ in $\mathrm{nm}\left(\epsilon_{\max }\right.$ in $\left.\left.\mathrm{dm}^{3} \mathrm{~mol}^{-1} \mathrm{~cm}^{-1}\right)\right]: 478(143), 348(146) \cdot{ }^{13} \mathrm{C}$ n.m.r. $\delta(0 \cdot 1 \mathrm{M} \mathrm{DCl}): 80 \cdot 51, \mathrm{CHNO}_{2} ; 57 \cdot 98,55 \cdot 87,55 \cdot 77,54 \cdot 35,54 \cdot 16,54 \cdot 05,53 \cdot 95,50 \cdot 73$, $49 \cdot 15,46 \cdot 41,43 \cdot 25, \mathrm{CH}_{2} \mathrm{~N} ; 43 \cdot 14, \mathrm{C}_{\mathrm{q}} \mathrm{CH}_{3} ; 20 \cdot 13, \mathrm{CH}_{3}$. The peak at $80 \cdot 51$ diminished with time as the attached proton exchanged with deuterium.

A sample was also converted into the diethyldithiocarbamate $\left(E_{2} \mathrm{dtc}^{-}\right)$salt by treating an aqueous solution of the chloride salt with $\mathrm{Na}\left(\mathrm{Et}_{2} \mathrm{dtc}\right)$, filtering the precipitate, and washing with water (Found: $\mathrm{C}, 40 \cdot 5 ; \mathrm{H}, 7 \cdot 9 ; \mathrm{N}, 16 \cdot 1 ; \mathrm{S}, 21 \cdot 9 . \mathrm{C}_{29} \mathrm{H}_{63} \mathrm{CoN}_{10} \mathrm{O}_{2} \mathrm{~S}_{6} .2 \mathrm{H}_{2} \mathrm{O}$ requires $\mathrm{C}$, $40 \cdot 0 ; \mathrm{H}, 7 \cdot 8 ; \mathrm{N}, 16 \cdot 1 ; \mathrm{S}, 22 \cdot 1 \%)$.

\section{(5) $\left.\mathrm{Co}\left(6-\mathrm{Me}, 13-\mathrm{NO}_{2}, 6-\mathrm{CH}_{2} \mathrm{NHCH}_{2} \mathrm{CH}_{2} \mathrm{NH}_{2}-[14] \mathrm{aneN} \mathrm{N}_{4}\right)\right] \mathrm{Cl}_{3} .3 \mathrm{H}_{2} \mathrm{O}$ (Isomer B), (6-(4-Amino-2-azabutyl)-6-methyl-13-nitro-1,4,8,11-tetraazacyclotetradecane) cobalt(III) Chloride Trihydrate}

The product from the previous preparation (isomer $A$ ) was maintained at $20^{\circ} \mathrm{C}$ in aqueous solution for $24 \mathrm{~h}$. The solution was loaded onto a column of SP-Sephadex C-25, and eluted with $0.1 \mathrm{M} \mathrm{K}_{2} \mathrm{SO}_{4}$. The single band which was obtained was loaded onto Dowex 50W-X2, washed with $1 \mathrm{M} \mathrm{HCl}$, eluted with $4 \mathrm{M} \mathrm{HCl}$, and evaporated to dryness. A sample was recrystallized from $\mathrm{HCl}$ /acetone (Found: $\mathrm{C}, 30 \cdot 7 ; \mathrm{H}, 6 \cdot 8 ; \mathrm{Cl}, 19 \cdot 9 ; \mathrm{N}, 17 \cdot 6 . \mathrm{C}_{14} \mathrm{H}_{33} \mathrm{Cl}_{3} \mathrm{CoN}_{7} \mathrm{O}_{2} .3 \mathrm{H}_{2} \mathrm{O}$ requires $\mathrm{C}, 30.5 ; \mathrm{H}, 7 \cdot 1 ; \mathrm{Cl}, 19 \cdot 3 ; \mathrm{N}, 17 \cdot 8 \%)$. Electronic spectrum in aqueous $\mathrm{HCl}(0.1 \mathrm{M})$ $\left[\lambda_{\max }\right.$ in $\mathrm{nm}\left(\epsilon_{\max }\right.$ in $\left.\mathrm{dm}^{3} \mathrm{~mol}^{-1} \mathrm{~cm}^{-1}\right]$ : $478(137), 346(132) .{ }^{13} \mathrm{C}$ n.m.r. $\delta(0 \cdot 1 \mathrm{M} \mathrm{DCl})$ : $76 \cdot 77, \mathrm{CHNO}_{2} ; 57 \cdot 96,56 \cdot 16,55 \cdot 95,54 \cdot 43,54 \cdot 30,54 \cdot 16,53 \cdot 74,50 \cdot 77,50 \cdot 29,47 \cdot 39,43 \cdot 08$, $\mathrm{CH}_{2} \mathrm{~N} ; 43 \cdot 06, \mathrm{C}_{\mathrm{q}} \mathrm{CH}_{3}$, overlapping; $20 \cdot 16, \mathrm{CH}_{3}$.

A sample was also converted into the diethyldithiocarbamate $\left(\mathrm{Et}_{2} \mathrm{dtc}^{-}\right)$salt as described for isomer $A$ (Found: $\mathrm{C}, 40 \cdot 6 ; \mathrm{H}, 7 \cdot 9 ; \mathrm{N}, 16 \cdot 1 ; \mathrm{S}, 21 \cdot 3 . \mathrm{C}_{29} \mathrm{H}_{63} \mathrm{CoN}_{10} \mathrm{O}_{2} \mathrm{~S}_{6} \cdot \mathrm{H}_{2} \mathrm{O}$ requires $\mathrm{C}$, $40 \cdot 8 ; \mathrm{H}, 7 \cdot 7 ; \mathrm{N}, 16 \cdot 4 ; \mathrm{S}, 22 \cdot 6 \%)$.

\section{Interconversion of Isomers $\mathrm{A}$ and $\mathrm{B}$, and Proton Exchange}

In neutral aqueous solution, isomer $A$ was converted into isomer $B$ at $20^{\circ} \mathrm{C}$ over $24 \mathrm{~h}$, as shown by the n.m.r. experiments. In $0.1 \mathrm{M} \mathrm{DCl}$ after $24 \mathrm{~h}$ at $20^{\circ} \mathrm{C}$, although there was very little isomerization from $A$ to $B$, the ${ }^{13} \mathrm{C}$ resonance $\mathrm{CHNO}_{2}$ of isomer $A$ (at $80.5 \mathrm{ppm}$ ) had been replaced by a triplet at almost the same chemical shift $(80.2 \mathrm{ppm})$. There was no apparent change in the corresponding resonance of isomer $B(76.7 \mathrm{ppm})$ at the same $\mathrm{pD}$ over the same time scale. When isomer $B$ was dissolved in base and quenched with acid after a few seconds, the n.m.r. showed that it had been converted quantitatively into isomer $A$.

Both isomers $A$ and $B$ contain a number of distinct broad bands between 4.5 and $7.5 \mathrm{ppm}$, corresponding to $\mathrm{NH}$ resonances. These disappear on exchange with solvent deuterium. In 
neutral solution this exchange is complete in $<1 \mathrm{~h}$ at $20^{\circ} \mathrm{C}$, and the rate decreases with decreasing $\mathrm{pH}$. In $1 \mathrm{M} \mathrm{DCl}$ at $95^{\circ} \mathrm{C}$, complete exchange occurs in c. $45 \mathrm{~min}$, whereas in $7 \mathrm{M}$ $\mathrm{DCl}$ it is complete after $16 \mathrm{~h}$.

\section{(4) $\mathrm{Co}\left(6-\mathrm{Me}, 13-\mathrm{NO}_{2}, 6-\mathrm{CH}_{2} \mathrm{NHCH}_{2} \mathrm{CH}_{2} \mathrm{NH}_{2}-[14]\right.$ ane $\left.\left.\mathrm{N}_{4}-\mathrm{H}^{+}\right)\right]^{2+}$ (Deprotonated Species from Isomer $\mathrm{A}$ or $\mathrm{B}$ )}

A sample of either isomer $A$ or $B$ was dissolved in $\mathrm{D}_{2} \mathrm{O}$, and $\mathrm{K}_{2} \mathrm{CO}_{3}$ was added. The ${ }^{1} \mathrm{H}$ and ${ }^{13} \mathrm{C}$ n.m.r. spectra of the initial product showed no change over $12 \mathrm{~h}$ at $22^{\circ} \mathrm{C} .{ }^{1} \mathrm{H}$ n.m.r. $\delta$ $\left(\mathrm{D}_{2} \mathrm{O}\right): 4 \cdot 35, \mathrm{~d}, J 13 \mathrm{~Hz}, 1 \mathrm{H} ; 4 \cdot 01$, d, $J 13 \mathrm{~Hz}, 1 \mathrm{H} ; 3 \cdot 48, \mathrm{~d}, J 13 \mathrm{~Hz}, 1 \mathrm{H} ; 3 \cdot 2-2 \cdot 2$, complex pattern, $19 \mathrm{H} ; 0.93, \mathrm{~s}, 3 \mathrm{H}, \mathrm{CH}_{3} .{ }^{13} \mathrm{C}$ n.m.r. $\delta\left(\mathrm{D}_{2} \mathrm{O}\right): 95 \cdot 29, \mathrm{C}^{-} \mathrm{NO}_{2} ; 57 \cdot 84,56 \cdot 39,55 \cdot 90$, $54 \cdot 31,54 \cdot 12,54 \cdot 04,52 \cdot 98,50 \cdot 63,49 \cdot 96,46 \cdot 64,43 \cdot 09, \mathrm{CH}_{2} \mathrm{~N} ; 43 \cdot 09, \mathrm{C}_{\mathrm{q}} \mathrm{CH}_{3}$, overlapping; $20 \cdot 40, \mathrm{CH}_{3}$.

(6) $\left[\mathrm{Co}\left(\mathrm{Me}, \mathrm{OH}\right.\right.$-absar)] $\mathrm{Cl}_{3} .3 \mathrm{H}_{2} \mathrm{O}$ (1-Hydroxy-8-methyl-3,6,10,13,15,18-hexaazabicyclo[6.6.5/nonadecane) cobalt(III) Chloride Trihydrate)

A sample of either isomer $A$ or $B$ was heated at $80^{\circ} \mathrm{C}$ in water (or aqueous $0.2 \mathrm{M} \mathrm{K}_{2} \mathrm{SO}_{4}$ ) for $7 \mathrm{~h}$. It was diluted and loaded onto a column of SP-Sephadex, and eluted with $0.08 \mathrm{M}$ $\mathrm{K}_{2} \mathrm{SO}_{4}$. Two bands were collected. The first band corresponded to a small amount of unreacted starting material, and the second band was freed of eluent by treatment with Dowex $/ \mathrm{HCl}$ as described above, to yield the desired product. Yield $>90 \%$.

A sample was recrystallized from water/acetone (Found: $\mathrm{C}, 32 \cdot 3 ; \mathrm{H}, 7 \cdot 8 ; \mathrm{Cl}, 20 \cdot 6 ; \mathrm{N}$, 16.1. $\mathrm{C}_{14} \mathrm{H}_{32} \mathrm{Cl}_{3} \mathrm{CoN}_{6} \mathrm{O} .3 \mathrm{H}_{2} \mathrm{O}$ requires $\mathrm{C}, 32 \cdot 4 ; \mathrm{H}, 7 \cdot 4 ; \mathrm{Cl}, 20 \cdot 5 ; \mathrm{N}, 16 \cdot 2 \%$ ). Electronic spectrum in aqueous $\mathrm{HCl}(0 \cdot 1 . \mathrm{M})\left[\lambda_{\max }\right.$ in $\mathrm{nm}\left(\epsilon_{\max }\right.$ in $\left.\left.\mathrm{dm}^{3} \mathrm{~mol}^{-1} \mathrm{~cm}^{-1}\right)\right]: 458(175), 336$ (172). ${ }^{1} \mathrm{H}$ n.m.r. $\left(\mathrm{D}_{2} \mathrm{O}\right)$ : the proton spectrum was complex, but was readily differentiated from the precursors and from $\left[\mathrm{Co}\left(\mathrm{Me}, \mathrm{NO}_{2} \text {-sar }\right)^{3+}\right.$ by doublets at $\delta 2 \cdot 38(\mathrm{~J} \mathrm{14} \mathrm{Hz}), 2.58$ and $2.64(J 6 \mathrm{~Hz})$ and the cap methyl singlet at $0.92 .{ }^{13} \mathrm{C}$ n.m.r. $\delta\left(\mathrm{D}_{2} \mathrm{O}\right): 91.73, \mathrm{C}_{\mathrm{q}} \mathrm{OH} ; 60.35$, $59 \cdot 93,59 \cdot 20,58 \cdot 73,57 \cdot 28,55 \cdot 23,53 \cdot 49,52 \cdot 38,51 \cdot 83,50 \cdot 59,43 \cdot 82, \mathrm{CH}_{2} \mathrm{~N} ; 43 \cdot 51, \mathrm{C}_{\mathrm{q}} \mathrm{CH}_{3}$; $20 \cdot 62, \mathrm{CH}_{3}$.

\section{$[\mathrm{Co}(\mathrm{Me}, \mathrm{OH}-\mathrm{absar})]\left(\mathrm{ClO}_{4}\right)_{2}$}

Caution! Transition metal perchlorates are potentially hazardous, and the appropriate precautions should be taken.

A solution of $[\mathrm{Co}(\mathrm{Me}, \mathrm{OH}$-absar $)] \mathrm{Cl}_{3} .3 \mathrm{H}_{2} \mathrm{O}(93 \mathrm{mg})$ in $5 \mathrm{ml}$ water was degassed with argon. Zinc powder (c. 100 mesh) was added; this led to a rapid loss of the yellow colour. After $1 \mathrm{~min}$, the solution was filtered into an argon-saturated aqueous solution of $\mathrm{NaClO}_{4}(15 \mathrm{ml})$ containing sufficient additional solid $\mathrm{NaClO}_{4}$ to ensure that the final solution was almost saturated. The excess salt dissolved, and a fine solid precipitated. The mixture was left for $3 \mathrm{~h}$ to ensure complete precipitation. The product was collected by filtration, washed with argon-saturated methanol, and dried under a stream of argon. Yield $102 \mathrm{mg}$ (c. 100\%) of pale greyish powder. This was used to record the spectrum of the cobalt(II) complex. Electronic spectrum in $\mathrm{H}_{2} \mathrm{O}\left[\lambda_{\max }\right.$ in $\mathrm{nm}\left(\epsilon_{\max }\right.$ in $\left.\left.\mathrm{dm}^{3} \mathrm{~mol}^{-1} \mathrm{~cm}^{-1}\right)\right]: 870(6), 658(3 \cdot 4), 550(5 \cdot 3), 467$ (13). The concentration of complex (and hence $\epsilon$ ) was determined by recording the spectrum of the solution after reoxidation to the cobalt(III) state.

\section{X-Ray Crystal Structure Determination}

Crystal data.-Orange crystals of $[\mathrm{Co}(\mathrm{Me}, \mathrm{OH}$-absar) $)] \mathrm{Cl}_{3}, \mathrm{H}_{2} \mathrm{O}($ c. 0.2 by 0.2 by $0.2 \mathrm{~mm})$ suitable for crystallography were grown from aqueous acetone solution kept at $-5^{\circ} \mathrm{C}$. $\mathrm{C}_{14} \mathrm{H}_{34} \mathrm{Cl}_{3} \mathrm{CoN}_{6} \mathrm{O}_{2}$, monoclinic, $P 2_{1 / n}$ (No. 14), point group $2 / m, a 9.862(2), b 17 \cdot 841(1)$, $c 11.910(1) \AA, \beta 93.47(2)^{\circ}, V 2091.7 \AA^{3}, Z 4, D_{\mathrm{c}} 1.529, D_{\mathrm{m}} 1.524 \mathrm{~g} \mathrm{~cm}^{-3}, \lambda$ (Mo K $\alpha$ ) $0.7107 \AA, \mu 12 \cdot 26 \mathrm{~cm}^{-1}, F(000) 1008 \cdot 0, T 293 \mathrm{~K}$.

Structure solution and refinement.-Three-dimensional intensity data were collected on an Enraf-Nonius CAD4 diffractometer by using graphite monochromatized Mo $\mathrm{K} \alpha$ radiation to a $\theta$ limit of $23.5^{\circ}$ in the $\omega / 2 \theta$ mode. The data were corrected for Lorentz and polarization effects but 
not for absorption. The structure was solved by using MULTAN- $80,{ }^{17}$ and refined by the full-matrix least-squares program LALs. ${ }^{18}$ The refinement of the scale factor, positional and anisotropic thermal parameters of non-hydrogen atoms, as well as positional and isotropic thermal parameters of hydrogen atoms, converged at $R 0.042$ and $R_{w} 0.052$, where $R=\sum|| F_{\circ}|-| F_{\mathrm{c}}|| / \sum\left|F_{\mathrm{o}}\right|$ and $R_{w}=\sum\left(w|| F_{\mathrm{o}}|-| F_{\mathrm{c}} \mid\right)^{1 / 2} / \sum\left(w\left|F_{\mathrm{o}}\right|\right)^{1 / 2} .^{18}$ The weighting function used was $w=1$. The shifts in the parameters in the last cycle were less than $0.0001 \sigma$.

A perspective view of the molecule drawn with PLUTO, ${ }^{19}$ with the numbering scheme, is shown in Fig. 2. Fractional coordinates are listed in Table 2. Tables 3-5 list the bond lengths, bond angles and torsional angles respectively. Deposited material includes hydrogen atom parameters, selected least-squares planes, and a figure showing the stereo packing of the complex (these can be obtained on application to the Australian Journal of Chemistry, P.O. Box 89, East Melbourne, Vic. 3002).

\section{Results and Discussion}

\section{Reactions}

Although the cobalt complexes of 'sar' and its derivatives are noted for their generally remarkable stability even in the cobalt(II) state, ${ }^{1,2}$ the nitro-capped species are susceptible to a retro-Mannich reaction in base. The reactions of $\left[\mathrm{Co}\left(\mathrm{Me}, \mathrm{NO}_{2} \text {-sar }\right)\right]^{3+}$ in base have been followed both spectrophotometrically and by ${ }^{1} \mathrm{H}$ and ${ }^{13} \mathrm{C}$ n.m.r.

The ${ }^{1} \mathrm{H}$ n.m.r. spectrum of the $C_{3}$ ion $\left[\mathrm{Co}\left(\mathrm{Me}, \mathrm{NO}_{2} \text {-sar) }\right]^{3+}\right.$ is complex (Fig. 1a), but it has been possible to assign the resonances by comparison with the related complexes which have $D_{3}$ symmetry, ${ }^{2}$ i.e. $\left[\mathrm{Co}\left(\left(\mathrm{NO}_{2}\right)_{2} \text {-sar }\right)\right]^{3+}$ and $\left[\mathrm{Co}\left(\mathrm{Me}_{2} \text {-sar }\right)\right]^{3+}$. Addition of $\mathrm{NaOH}$ to a solution of $\left[\mathrm{Co}\left(\mathrm{Me}, \mathrm{NO}_{2} \text {-sar }\right)\right]^{3+}$ leads to rapid darkening of the yellow solution ( $<1 \mathrm{~ms}$ ) resulting from deprotonation of a coordinated secondary amine. The positions of the visible bands are not altered to any great extent, although their intensities increase significantly, and an intense tail from the u.v. extends to $c .400 \mathrm{~nm}$. The proton spectrum of the deprotonated species $\left[\mathrm{Co}\left(\mathrm{Me}, \mathrm{NO}_{2} \text {-sar }-\mathrm{H}^{+}\right)\right]^{2+}$ (Fig. $\left.1 b\right)$ has a pattern similar to that of the precursor $\left[\mathrm{Co}\left(\mathrm{Me}, \mathrm{NO}_{2} \text {-sar }\right)\right]^{3+}$ (i.e. the average solution symmetry is retained) although the peak positions are shifted; this implies that there is a rapid exchange of the remaining amine protons with the deprotonated nitrogen. The signals least affected are those in the cap bearing the methyl substituent; this implies that the deprotonation involves principally the amines nearer the $\mathrm{NO}_{2}$-capped end. The ${ }^{13} \mathrm{C}$ n.m.r. spectrum also shows that the $C_{3}$ symmetry has been retained on the n.m.r. time scale, and that the amine protons are switching rapidly among the three sites. When a sample of $\left[\mathrm{Co}\left(\mathrm{Me}, \mathrm{NO}_{2} \text {-sar }\right)\right]^{3+}$ containing only 1 equiv, of base was reacidified after $90 \mathrm{~min}$, the starting material was recovered almost quantitatively. Similar behaviour has been observed previously with $\left[\mathrm{Co}\left(\left(\mathrm{NO}_{2}\right)_{2} \text {-sar }\right)\right]^{3+}$, and the crystal structure of $\left[\mathrm{Co}\left(\left(\mathrm{NO}_{2}\right)_{2}-\mathrm{sar}-\mathrm{H}^{+}\right)\right]\left(\mathrm{ClO}_{4}\right)_{2}$ has been reported, ${ }^{2}$ but the reaction sequence following deprotonation is more complex.

${ }^{17}$ Main, P., Hull, S. E., Lessinger, L., Germain, G., Decelerq, J. P., and Woolfson, M. M., 'MUlTaN-80', A System of Computer Programs for Automatic Structure Solution, University of York, England, 1980.

${ }^{18}$ Gantzel, P. K., Sparks, R. A., and Trueblood, K. N., 'Programs-Uclals-1', University of California, 1961.

${ }^{19}$ Motherwell, W. D., and Clegg, W., 'Pluto', Program for Plotting Molecular and Crystal Structures, University of Cambridge, England, 1978. 


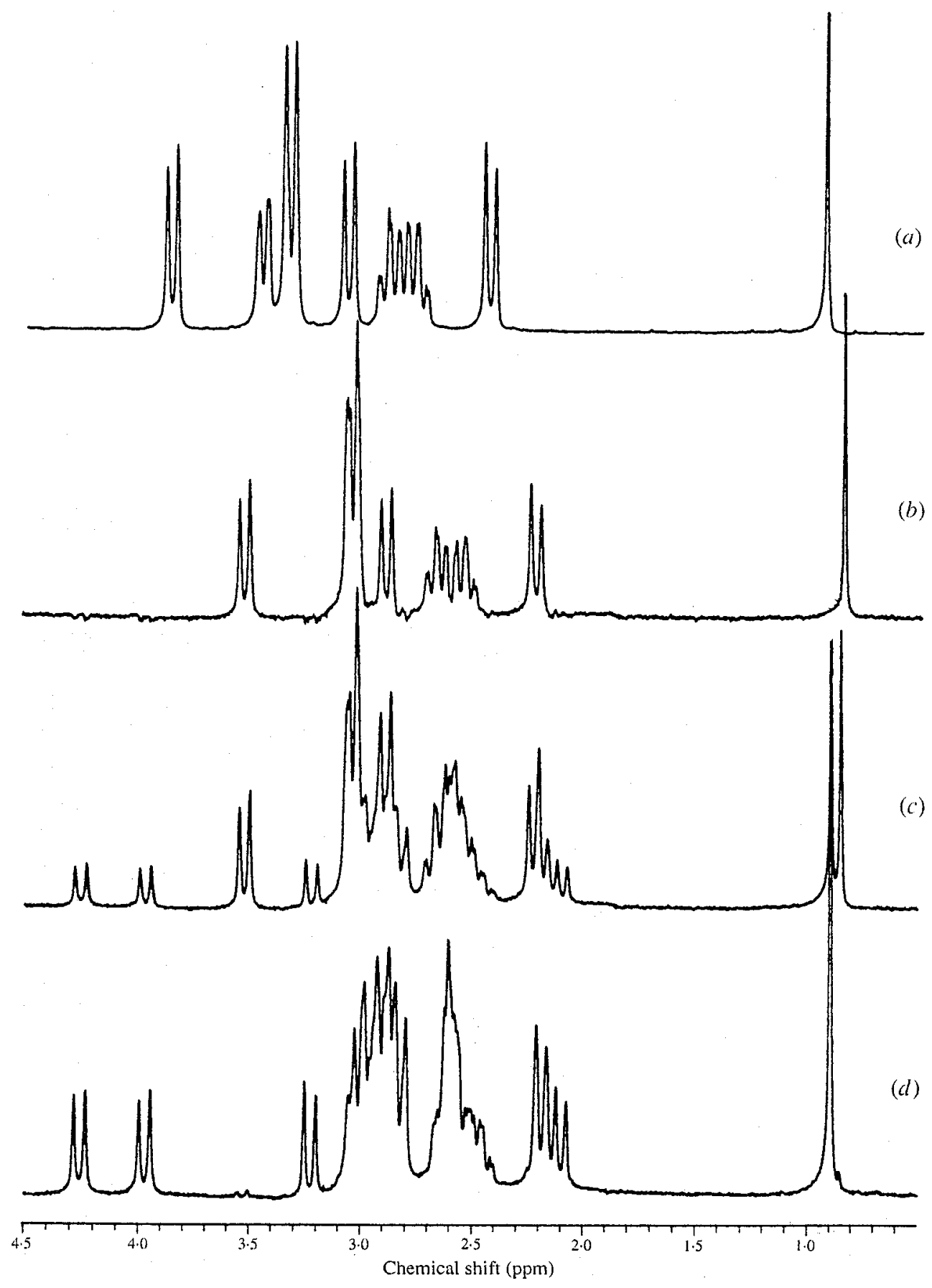

Fig. 1. ${ }^{1} \mathrm{H}$ n.m.r. spectra of solutions of $\left[\mathrm{Co}\left(\mathrm{Me}, \mathrm{NO}_{2} \text {-sar }\right)\right]^{3+}(c .0 .3 \mathrm{M})$ in: $(a) \mathrm{D}_{2} \mathrm{O} ;(b)$ $1 \mathrm{M} \mathrm{NaOD}$ at $t=0$ [obtained by subtraction of $(d)$ from $(c)$ after normalization]; $(c) 1 \mathrm{M}$ $\mathrm{NaOD}$ after $1 \mathrm{~min} ;(d) 1 \mathrm{M} \mathrm{NaOD}$ after $10 \mathrm{~min}$. 
Addition of more than 1 equiv. of base to a solution of $\left[\mathrm{Co}\left(\mathrm{Me}, \mathrm{NO}_{2}\right.\right.$-sar $\left.)\right] \mathrm{Cl}_{3}$ leads to the formation of a deprotonated species [(4) in Scheme 1] with one fewer carbon atoms, as shown by microanalysis and ${ }^{13} \mathrm{C}$ n.m.r., and loss of the $C_{3}$ symmetry. The reaction follows clean first-order kinetics in excess base, and the $\left[\mathrm{OH}^{-}\right]$dependence gives rise to the rate law

$$
k_{\mathrm{obs}}=\frac{0 \cdot 15\left[\mathrm{OH}^{-}\right]}{1+14\left[\mathrm{OH}^{-}\right]}
$$

with a limiting rate in the high base concentration region $(1 \mathrm{M} \mathrm{OH}-)$. In $1 \mathrm{M}$ $\mathrm{NaOH}$, the reaction has a half-life of $c .1 \mathrm{~min}$. The visible spectrum of this deprotonated product was very similar to that of the $\left[\mathrm{Co}\left(\mathrm{Me}, \mathrm{NO}_{2} \text {-sar }-\mathrm{H}^{+}\right)\right]^{2+}$ precursor, but with the intensity reduced uniformly by about half. Quenching the product with acid gave (after workup) the reprotonated products (5a) and (5b), in which the $\mathrm{d}-\mathrm{d}$ bands of ${ }^{1} \mathrm{~T}_{1 \mathrm{~g}}$ and ${ }^{1} \mathrm{~T}_{2 \mathrm{~g}}$ origin had moved $c .7 \mathrm{~nm}$ to lower energy with respect to $\left[\mathrm{Co}\left(\mathrm{Me}, \mathrm{NO}_{2} \text {-sar }\right)\right]^{3+}$.

The formation of the deprotonated intermediate (4) from $\left[\mathrm{Co}\left(\mathrm{Me}, \mathrm{NO}_{2-}\right.\right.$ sar $\left.\left.-\mathrm{H}^{+}\right)\right]^{2+}$ was readily followed in the ${ }^{1} \mathrm{H}$ n.m.r. spectrum (Figs $1 c$ and $1 d$ ) by the appearance of a new methyl singlet $0.04 \mathrm{ppm}$ downfield from that of the precursor, the disappearance of the doublet at $3.52 \mathrm{ppm}$ and the appearance of three doublets at $4 \cdot 25,3.97$ and $3.22 \mathrm{ppm}(J 13 \mathrm{~Hz})$, which were assigned to three of the four $\mathrm{CH}_{2}$ protons remaining on the $\mathrm{NO}_{2}$ cap. The ${ }^{1} \mathrm{H}$ n.m.r. spectrum of the intermediate (4) formed in the reaction was identical with that obtained when either (5a) or (5b) was dissolved in $1 \mathrm{M} \mathrm{NaOD}$. It was not possible to obtain the ${ }^{1} \mathrm{H}$ n.m.r. spectrum of the deprotonated complex $\left[\mathrm{Co}\left(\mathrm{Me}, \mathrm{NO}_{2}-\mathrm{sar}-\mathrm{H}^{+}\right)\right]^{2+}$ in $1 \mathrm{~m} \mathrm{NaOD}$ due to the rapid subsequent reaction of this species. However, by using spectral editing techniques, it was possible to derive the spectrum of this species from the spectra recorded, 1 and $10 \mathrm{~min}$ after mixing (Figs $1 c$ and $1 d$ respectively). This spectrum is shown in Fig. 1b. It shows the same splitting pattern as the ${ }^{1} \mathrm{H}$ n.m.r. spectra of $\left[\mathrm{Co}\left(\mathrm{Me}, \mathrm{NO}_{2} \text {-sar }\right)\right]^{3+}$ in neutral solution, in aqueous $\mathrm{Na}_{2} \mathrm{CO}_{3}$ and in a solution with 1 equiv. of added $\mathrm{NaOD}$. The peak positions depend on the $\mathrm{pH}$, but the identical splitting patterns show that the deprotonated product initially formed in $1 \mathrm{M} \mathrm{NaOH}$ still preserves the symmetry of the parent $\left[\mathrm{Co}\left(\mathrm{Me}, \mathrm{NO}_{2} \text {-sar }\right)\right]^{3+}$ complex.

The ${ }^{13} \mathrm{C}$ n.m.r. spectrum of the reaction mixture after $10 \mathrm{~min}$ clearly showed the loss of one carbon atom and the attendant loss of symmetry, as well as the presence of a single product (4). This product reacted further with base only slowly, with a half-life of $c .4 \mathrm{~h}$. The products of the reaction included (amongst others) significant amounts of $[\mathrm{Co}(\operatorname{sen})]^{3+}\left[\operatorname{sen}=4,4^{\prime}, 4^{\prime \prime}\right.$ ethylidynetris(3-azabutan-1-amine)], the precursor of the capping reaction used to form $\left[\mathrm{Co}\left(\mathrm{Me}, \mathrm{NO}_{2} \text {-sar }\right)\right]^{3+}$.

The loss of the first methylene unit occurs through a retro-Mannich type reaction, involving deprotonation at a secondary nitrogen, followed by imine formation through carbanion dissociation from the negatively charged fragment. The imine is then hydrolysed under the basic conditions of the reaction (Scheme 1). Subsequent loss of a second methylene unit by a similar mechanism is significantly slower, presumably because in species (4) deprotonation occurs preferentially at the carbon atom bearing the $\mathrm{NO}_{2}$ group. The $\mathrm{p} K_{\mathrm{a}}$ of $\left(\mathrm{CH}_{3}\right)_{2} \mathrm{C}(\mathrm{H}) \mathrm{NO}_{2}$ is $c$. 


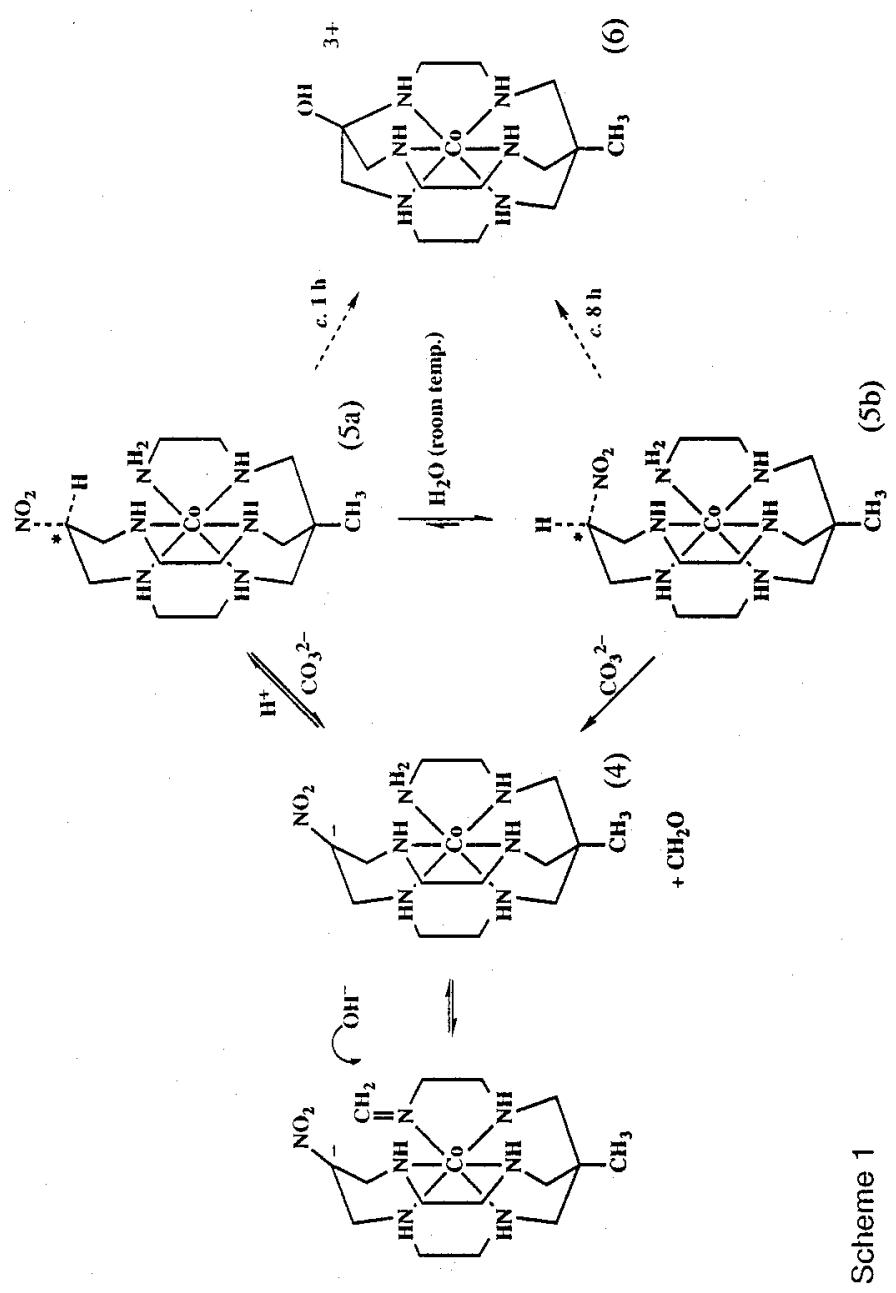

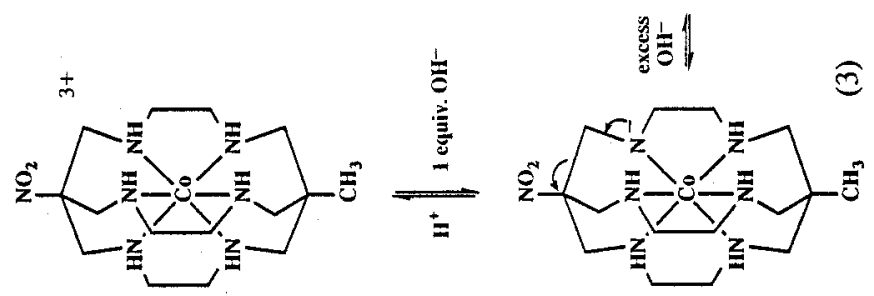


$7 \cdot 7,{ }^{20}$ and the presence of the $\mathrm{Co}^{3+}$ centre will lower the $\mathrm{p} K_{\mathrm{a}}$ even further.] This leads to a species where the carbanion is held close to the reaction centre by chelation, thus hindering deprotonation of another secondary amine. The presence of $[\mathrm{Co}(\mathrm{sen})]^{3+}$ as the principal decomposition product (together with the absence of the nitro product which had lost two methylene units) implies that rupture of the final methylene unit in the cap may be more rapid.

The difference in the rates of loss of the first and subsequent methylene units enabled the isolation of the intermediate species, by quenching the reaction mixture with acid after c. $15 \mathrm{~min}$. This gives a mixture of starting material and one product (designated isomer $A$ in the Experimental section). The product isomerizes under the conditions of the chromatography on the Sephadex column to another species (designated isomer $B$ ). These two isomers have been separated by chromatography and characterized by microanalysis and n.m.r. as tetraaza macrocyclic units with a pendant bidentate arm $\left(\mathrm{CH}_{2} \mathrm{NHCH}_{2} \mathrm{CH}_{2} \mathrm{NH}_{2}\right)$. They appear to differ only in the configuration about the $\mathrm{C}(\mathrm{H}) \mathrm{NO}_{2}$ carbon atom. The proton on this carbon atom is quite acidic in both isomers, but it is significantly more acidic in isomer $A$ than in isomer $B$. Proton exchange occurs more rapidly in isomer $A$, where it is readily exchanged at $22^{\circ} \mathrm{C}$ even in $0.1 \mathrm{M} \mathrm{DCl}$, as shown by the appearance of a triplet at $80.2 \mathrm{ppm}$ in the ${ }^{13} \mathrm{C}$ n.m.r. spectrum, corresponding to the formation of $>\mathrm{C}(\mathrm{D}) \mathrm{NO}_{2}$, and the concomitant loss of the \rangle $\mathrm{C}(\mathrm{H}) \mathrm{NO}_{2}$ resonance at $80.5 \mathrm{ppm}$.

If a solution of $\left[\mathrm{Co}\left(\mathrm{Me}, \mathrm{NO}_{2}\right.\right.$-sar $\left.)\right] \mathrm{Cl}_{3}$ that had been treated with excess base for $15 \mathrm{~min}$ then quenched with acid was kept acidified during chromatography and subsequent workup, only isomer $A$ was obtained. However, heating this isomer even in the solid state led to partial conversion into isomer $B$. In non-acidic solution, the conversion occurred readily at $20^{\circ} \mathrm{C}$. Treatment of either isomer with base $\left(\mathrm{K}_{2} \mathrm{CO}_{3}\right)$ gave a common deprotonated product, with ${ }^{1} \mathrm{H}$ and ${ }^{13} \mathrm{C}$ n.m.r. spectra corresponding to those observed for a solution of $\left[\mathrm{Co}\left(\mathrm{Me}, \mathrm{NO}_{2} \text {-sar }\right)\right]^{3+}$ in $\mathrm{D}_{2} \mathrm{O}$ with excess $\mathrm{NaOD}$ after $10 \mathrm{~min}$. Isomer $B$ was quantitatively reconverted into isomer $A$ by treatment with $\mathrm{K}_{2} \mathrm{CO}_{3}$ (or $\mathrm{NaOH}$ ) for a few seconds followed by quenching with acid. This experiment confirms that the two isomers are related by a simple deprotonation/inversion reaction.

The final product $[\mathrm{Co}(\mathrm{Me}, \mathrm{OH}-\mathrm{absar})]^{3+}(6)$ was readily obtained by heating a neutral aqueous solution of isomer $A$ at $c .90^{\circ} \mathrm{C}$ for $1 \mathrm{~h}$. However, under these conditions, isomer $A$ was also converted into isomer $B$, which in turn reacted considerably more slowly to give the product. Heating either isomer for $8 \mathrm{~h}$ at $c .90^{\circ} \mathrm{C}$ in neutral aqueous solution or in dilute acid $(c .0 .1 \mathrm{M})$, followed by SP-Sephadex chromatography (with $\mathrm{K}_{2} \mathrm{SO}_{4}$ as eluent), gave good yields of the final product, although significantly more decomposition (to unidentified products) was observed when this reaction was carried out with isomer $B$. The structure of the product (6) has been established by an X-ray crystallographic analysis (Fig. 2), and the details of the structure are discussed below,

The formation of the condensed cap species is argued to proceed through a Nef reaction ${ }^{21}$ followed by condensation of the carbonyl group with the deprotonated primary amine of the pendant arm (Scheme 2).

${ }^{20}$ Turnbull, D., and Maron, S. H., J. Am. Chem. Soc., 1943, 65, 212.

${ }^{21}$ For example, March, J., 'Advanced Organic Chemistry' p. 786 (John Wiley: New York 1985). 


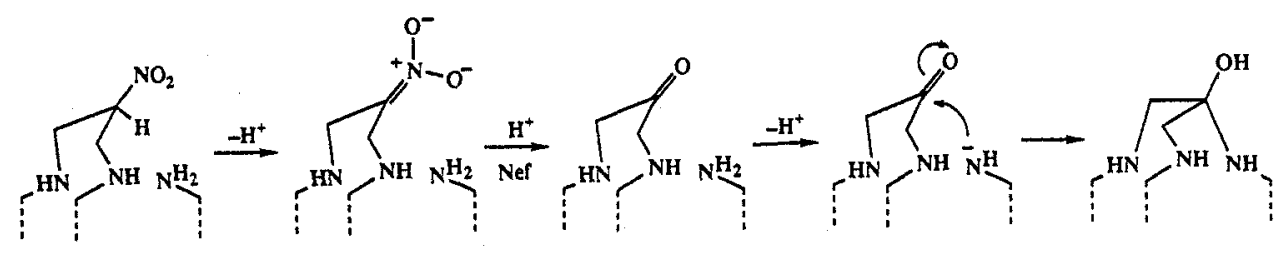

Scheme 2

The conversion of isomers $A$ and $B$ into the contracted cap product $[\mathrm{Co}(\mathrm{Me}, \mathrm{OH}-$ absar) $]^{3+}$ was readily followed by n.m.r. Although the ${ }^{1} \mathrm{H}$ n.m.r. spectra of all three compounds contain a complex overlapping pattern corresponding to the methylene units, the overlapping singlet resonances of the cap methyl groups of isomers $A$ and $B$ are clearly distinguishable from that of $[\mathrm{Co}(\mathrm{Me}, \mathrm{OH}-\mathrm{absar})]^{3+}$ which is $0.035 \mathrm{ppm}$ further upfield. Considering the close similarity of isomers $A$ and $B$, it is not surprising that their ${ }^{13} \mathrm{C}$ n.m.r. spectra contain a number of overlapping resonances. Still, they do display a number of resonances that can be used to differentiate them. In particular, the resonances at $80 \cdot 5,49 \cdot 2$ and $46.4 \mathrm{ppm}$ in isomer $A$, and at $76 \cdot 8,50.3$ and $47.4 \mathrm{ppm}$ in isomer $B$ are characteristic. The ${ }^{13} \mathrm{C}$ n.m.r. spectrum of $[\mathrm{Co}(\mathrm{Me}, \mathrm{OH}-\mathrm{absar})]^{3+}$ is quite different, and the cap methyl resonance is shifted $0.4 \mathrm{ppm}$ downfield from that of the two precursors.

Proton exchange and formation of $[\mathrm{Co}(\mathrm{Me}, \mathrm{OH}-\mathrm{absar})]^{3+}$ were observed even in concentrated acid $(7 \mathrm{M} \mathrm{DCl})$, although this required prolonged heating at $95^{\circ} \mathrm{C}$ and a significant amount of decomposition occurred. The ${ }^{13} \mathrm{C}$ and ${ }^{1} \mathrm{H}$ n.m.r. spectra of a solution of isomer $A$ heated in $7 \mathrm{M} \mathrm{DCl}$ at $c .90^{\circ} \mathrm{C}$ for $9 \mathrm{~h}$ showed three distinct methyl resonances, despite the fact that after workup only the starting materials (isomers $A$ and $B$ ) and product were observed. The methyl signals of isomers $A$ and $B$ overlap so only two resonances were expected from the three products. It is possible that the third methyl resonance corresponds to a complex containing the ketone intermediate which undergoes condensation with the primary coordinated amine only slowly at such low $\mathrm{pH}$. However, due to the partial decomposition that occurred under the experimental conditions, it was not possible to detect a carbonyl resonance in the ${ }^{13} \mathrm{C}$ n.m.r. spectrum of the $7 \mathrm{M} \mathrm{DCl}$ reaction solution.

The contracted cage species $[\mathrm{Co}(\mathrm{Me}, \mathrm{OH}-\mathrm{absar})]^{3+}$ eluted more slowly on SP-Sephadex (with $0.05 \mathrm{M} \mathrm{K}_{2} \mathrm{SO}_{4}$ ) than the two 'open cage' species (5a) and $(5 b)$, and it was readily purified this way. It was easily differentiated on the column by its more lemon-yellow appearance than the precursor species which both had the same orange colour that is characteristic of many of the cobalt(III) complexes based on the 'sar' and 'sen' frameworks.

\section{Structural Results (Fig. 2 and Tables 2-5)}

The structure of the complex cation $[\mathrm{Co}(\mathrm{Me}, \mathrm{OH}-\mathrm{absar})]^{3+}$ is shown in Fig. 2. The general structural features are rather similar to those of the $\left[\mathrm{Co}\left(\mathrm{Cl}, \mathrm{CH}_{2} \mathrm{Cl}-\right.\right.$ absar)] $\left(\mathrm{NO}_{3}\right)_{3}$ complex. ${ }^{16}$ The three five-membered chelate rings forming the ' $\mathrm{Co}(\mathrm{en})_{3}$ ' core adopt a $l e l_{2} o b$ conformation about the pseudo- $C_{3}$ axis in both 


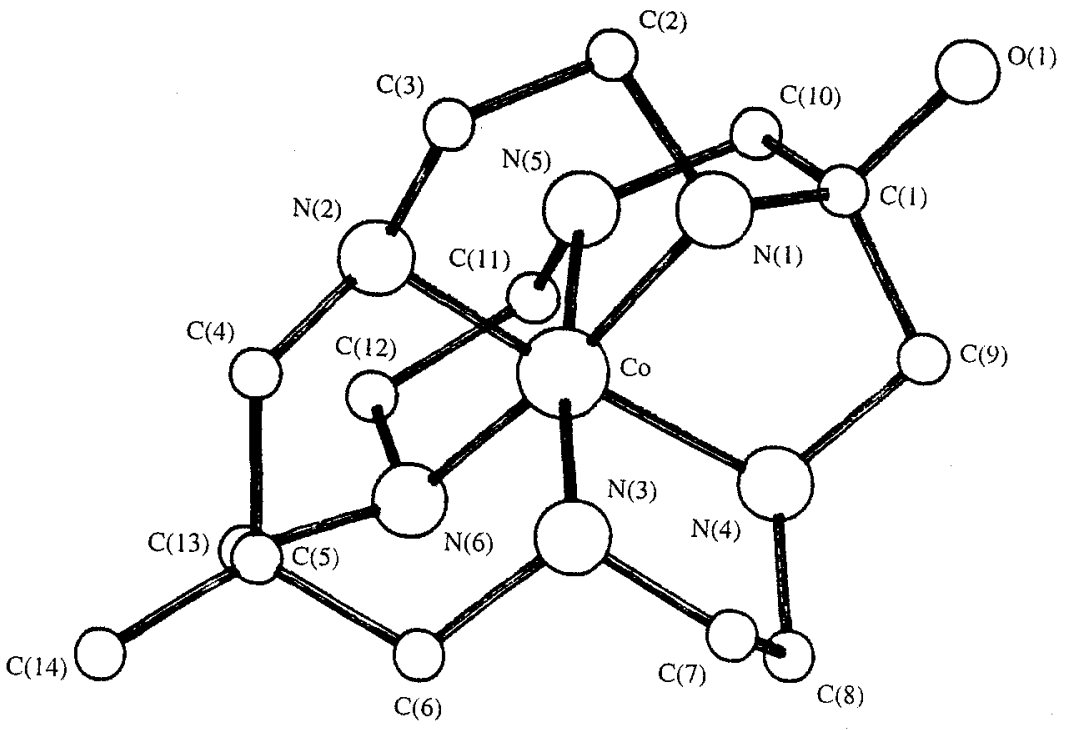

Fig. 2. Structure of the $\left[\mathrm{Co}^{\mathrm{III}}(\mathrm{Me}, \mathrm{OH}-\mathrm{absar})\right]^{3+}$ cation, showing the atomic numbering.

Table 2. Fractional atomic coordinates of the non-hydrogen atoms

\begin{tabular}{lccccccc}
\hline Atom & \multicolumn{1}{c}{$x$} & $y$ & $z$ & Atom & $x$ & $y$ & $z$ \\
\hline $\mathrm{Co}$ & $0.3211(2)$ & $0.1438(9)$ & $0.7065(10)$ & $\mathrm{C}(2)$ & $0.3351(13)$ & $0.2893(7)$ & $0.7972(10)$ \\
$\mathrm{Cl}(1)$ & $0.1856(4)$ & $0.4251(4)$ & $0.9799(3)$ & $\mathrm{C}(3)$ & $0.1971(13)$ & $0.2599(6)$ & $0.8251(10)$ \\
$\mathrm{Cl}(2)$ & $0.7616(4)$ & $0.3717(2)$ & $0.5873(3)$ & $\mathrm{C}(4)$ & $0.0492(13)$ & $0.1474(8)$ & $0.7900(10)$ \\
$\mathrm{Cl}(3)$ & $0.2349(5)$ & $0.3646(2)$ & $0.5192(3)$ & $\mathrm{C}(5)$ & $0.0622(12)$ & $0.0625(6)$ & $0.7521(10)$ \\
$\mathrm{O}$ & $0.4985(13)$ & $0.2358(7)$ & $0.0487(9)$ & $\mathrm{C}(6)$ & $0.1841(12)$ & $0.0240(6)$ & $0.8163(9)$ \\
$\mathrm{O}(1)$ & $0.6360(9)$ & $0.2813(5)$ & $0.7670(7)$ & $\mathrm{C}(7)$ & $0.4310(12)$ & $0.0363(7)$ & $0.8657(9)$ \\
$\mathrm{N}(1)$ & $0.4238(10)$ & $0.2217(5)$ & $0.7946(7)$ & $\mathrm{C}(8)$ & $0.5019(14)$ & $0.0208(7)$ & $0.7570(11)$ \\
$\mathrm{N}(2)$ & $0.1573(9)$ & $0.1962(5)$ & $0.7411(8)$ & $\mathrm{C}(9)$ & $0.6123(13)$ & $0.1520(7)$ & $0.7349(10)$ \\
$\mathrm{N}(3)$ & $0.3044(10)$ & $0.0777(5)$ & $0.8349(7)$ & $\mathrm{C}(10)$ & $0.4992(13)$ & $0.2436(7)$ & $0.5996(10)$ \\
$\mathrm{N}(4)$ & $0.5022(10)$ & $0.0935(5)$ & $0.6892(8)$ & $\mathrm{C}(11)$ & $0.3462(13)$ & $0.1628(6)$ & $0.4719(9)$ \\
$\mathrm{N}(5)$ & $0.3601(10)$ & $0.2088(5)$ & $0.5789(8)$ & $\mathrm{C}(12)$ & $0.2122(12)$ & $0.1194(6)$ & $0.4834(8)$ \\
$\mathrm{N}(6)$ & $0.2207(10)$ & $0.0798(6)$ & $0.5964(9)$ & $\mathrm{C}(13)$ & $0.0795(12)$ & $0.0582(6)$ & $0.6267(9)$ \\
$\mathrm{C}(1)$ & $0.5452(11)$ & $0.2263(8)$ & $0.7246(9)$ & $\mathrm{C}(14)$ & $-0.0712(13)$ & $0.0214(8)$ & $0.7785(12)$ \\
\hline
\end{tabular}

Table 3. Bond lengths $(\AA)$ involving non-hydrogen atoms

\begin{tabular}{llllll}
\hline \multicolumn{1}{c}{ Atoms } & Distance & \multicolumn{1}{c}{ Atoms } & Distance & \multicolumn{1}{c}{ Atoms } & Distance \\
\hline Co-N $(1)$ & $1.983(10)$ & $\mathrm{N}(2)-\mathrm{C}(4)$ & $1.519(16)$ & $\mathrm{C}(1)-\mathrm{C}(9)$ & $1.482(19)$ \\
$\mathrm{Co}-\mathrm{N}(2)$ & $1.933(10)$ & $\mathrm{N}(3)-\mathrm{C}(6)$ & $1.530(15)$ & $\mathrm{C}(1)-\mathrm{C}(10)$ & $1.561(16)$ \\
$\mathrm{Co}-\mathrm{N}(3)$ & $1.946(9)$ & $\mathrm{N}(3)-\mathrm{C}(7)$ & $1.477(16)$ & $\mathrm{C}(2)-\mathrm{C}(3)$ & $1.514(18)$ \\
$\mathrm{Co}-\mathrm{N}(4)$ & $2 \cdot 020(10)$ & $\mathrm{N}(4)-\mathrm{C}(8)$ & $1.528(16)$ & $\mathrm{C}(4)-\mathrm{C}(5)$ & $1.588(18)$ \\
$\mathrm{Co}-\mathrm{N}(5)$ & $1.969(9)$ & $\mathrm{N}(4)-\mathrm{C}(9)$ & $1.579(16)$ & $\mathrm{C}(5)-\mathrm{C}(6)$ & $1.546(17)$ \\
$\mathrm{Co}-\mathrm{N}(6)$ & $1.961(10)$ & $\mathrm{N}(5)-\mathrm{C}(10)$ & $1.512(16)$ & $\mathrm{C}(5)-\mathrm{C}(13)$ & $1.516(16)$ \\
$\mathrm{O}(1)-\mathrm{C}(1)$ & $1.402(15)$ & $\mathrm{N}(5)-\mathrm{C}(11)$ & $1.515(14)$ & $\mathrm{C}(5)-\mathrm{C}(14)$ & $1.555(15)$ \\
$\mathrm{N}(1)-\mathrm{C}(1)$ & $1.502(15)$ & $\mathrm{N}(6)-\mathrm{C}(12)$ & $1.518(14)$ & $\mathrm{C}(7)-\mathrm{C}(8)$ & $1.534(17)$ \\
$\mathrm{N}(1)-\mathrm{C}(2)$ & $1.491(16)$ & $\mathrm{N}(6)-\mathrm{C}(13)$ & $1.509(15)$ & $\mathrm{C}(11)-\mathrm{C}(12)$ & $1.544(17)$ \\
$\mathrm{N}(2)-\mathrm{C}(3)$ & $1.549(15)$ & & & & \\
\hline
\end{tabular}


Table 4. Bond angles (degrees) involving non-hydrogen atoms

\begin{tabular}{lrll}
\hline \multicolumn{1}{c}{ Atoms } & Angle & \multicolumn{1}{c}{ Atoms } & Angle \\
\hline $\mathrm{N}(1)-\mathrm{Co}-\mathrm{N}(2)$ & $87 \cdot 4(4)$ & $\mathrm{Co}-\mathrm{N}(5)-\mathrm{C}(11)$ & $108 \cdot 5(7)$ \\
$\mathrm{N}(1)-\mathrm{Co}-\mathrm{N}(3)$ & $94 \cdot 2(4)$ & $\mathrm{C}(10)-\mathrm{N}(5)-\mathrm{C}(11)$ & $113 \cdot 3(9)$ \\
$\mathrm{N}(1)-\mathrm{Co}-\mathrm{N}(4)$ & $86 \cdot 5(4)$ & $\mathrm{Co}-\mathrm{N}(6)-\mathrm{C}(12)$ & $108 \cdot 6(7)$ \\
$\mathrm{N}(1)-\mathrm{Co}-\mathrm{N}(5)$ & $83 \cdot 0(4)$ & $\mathrm{Co}-\mathrm{N}(6)-\mathrm{C}(13)$ & $115 \cdot 1(7)$ \\
$\mathrm{N}(1)-\mathrm{Co}-\mathrm{N}(6)$ & $169 \cdot 4(4)$ & $\mathrm{C}(12)-\mathrm{N}(6)-\mathrm{C}(13)$ & $109 \cdot 2(9)$ \\
$\mathrm{N}(2)-\mathrm{Co}-\mathrm{N}(3)$ & $90 \cdot 8(4)$ & $\mathrm{O}(1)-\mathrm{C}(1)-\mathrm{N}(1)$ & $110 \cdot 5(9)$ \\
$\mathrm{N}(2)-\mathrm{Co}-\mathrm{N}(4)$ & $172 \cdot 8(4)$ & $\mathrm{O}(1)-\mathrm{C}(1)-\mathrm{C}(9)$ & $108 \cdot 9(10)$ \\
$\mathrm{N}(2)-\mathrm{Co}-\mathrm{N}(5)$ & $94 \cdot 8(4)$ & $\mathrm{O}(1)-\mathrm{C}(1)-\mathrm{C}(10)$ & $110 \cdot 3(10)$ \\
$\mathrm{N}(2)-\mathrm{Co}-\mathrm{N}(6)$ & $91 \cdot 7(4)$ & $\mathrm{N}(1)-\mathrm{C}(1)-\mathrm{C}(9)$ & $105 \cdot 8(10)$ \\
$\mathrm{N}(3)-\mathrm{Co}-\mathrm{N}(4)$ & $85 \cdot 9(4)$ & $\mathrm{N}(1)-\mathrm{C}(1)-\mathrm{C}(10)$ & $110 \cdot 1(9)$ \\
$\mathrm{N}(3)-\mathrm{Co}-\mathrm{N}(5)$ & $173 \cdot 6(4)$ & $\mathrm{C}(9)-\mathrm{C}(1)-\mathrm{C}(10)$ & $111 \cdot 0(10)$ \\
$\mathrm{N}(3)-\mathrm{Co}-\mathrm{N}(6)$ & $96 \cdot 3(4)$ & $\mathrm{N}(1)-\mathrm{C}(2)-\mathrm{C}(3)$ & $105 \cdot 1(10)$ \\
$\mathrm{N}(4)-\mathrm{Co}-\mathrm{N}(5)$ & $88 \cdot 1(4)$ & $\mathrm{N}(2)-\mathrm{C}(3)-\mathrm{C}(2)$ & $108 \cdot 0(9)$ \\
$\mathrm{N}(4)-\mathrm{Co}-\mathrm{N}(6)$ & $95 \cdot 0(4)$ & $\mathrm{N}(2)-\mathrm{C}(4)-\mathrm{C}(5)$ & $111 \cdot 5(10)$ \\
$\mathrm{N}(5)-\mathrm{Co}-\mathrm{N}(6)$ & $86 \cdot 6(4)$ & $\mathrm{C}(4)-\mathrm{C}(5)-\mathrm{C}(6)$ & $110 \cdot 9(10)$ \\
$\mathrm{Co}-\mathrm{N}(1)-\mathrm{C}(1)$ & $98 \cdot 2(7)$ & $\mathrm{C}(4)-\mathrm{C}(5)-\mathrm{C}(13)$ & $110 \cdot 1(10)$ \\
$\mathrm{Co}-\mathrm{N}(1)-\mathrm{C}(2)$ & $107 \cdot 3(7)$ & $\mathrm{C}(4)-\mathrm{C}(5)-\mathrm{C}(14)$ & $108 \cdot 0(10)$ \\
$\mathrm{C}(1)-\mathrm{N}(1)-\mathrm{C}(2)$ & $117 \cdot 2(9)$ & $\mathrm{C}(6)-\mathrm{C}(5)-\mathrm{C}(13)$ & $109 \cdot 5(9)$ \\
$\mathrm{Co}-\mathrm{N}(2)-\mathrm{C}(3)$ & $108 \cdot 1(7)$ & $\mathrm{C}(6)-\mathrm{C}(5)-\mathrm{C}(14)$ & $109 \cdot 5(9)$ \\
$\mathrm{Co}-\mathrm{N}(2)-\mathrm{C}(4)$ & $114 \cdot 8(7)$ & $\mathrm{C}(13)-\mathrm{C}(5)-\mathrm{C}(14)$ & $108 \cdot 8(9)$ \\
$\mathrm{C}(3)-\mathrm{N}(2)-\mathrm{C}(4)$ & $109 \cdot 2(9)$ & $\mathrm{N}(3)-\mathrm{C}(6)-\mathrm{C}(5)$ & $111 \cdot 5(9)$ \\
$\mathrm{Co}-\mathrm{N}(3)-\mathrm{C}(6)$ & $111 \cdot 5(7)$ & $\mathrm{N}(3)-\mathrm{C}(7)-\mathrm{C}(8)$ & $107 \cdot 6(10)$ \\
$\mathrm{Co}-\mathrm{N}(3)-\mathrm{C}(7)$ & $112 \cdot 8(7)$ & $\mathrm{N}(4)-\mathrm{C}(8)-\mathrm{C}(7)$ & $107 \cdot 9(10)$ \\
$\mathrm{C}(6)-\mathrm{N}(3)-\mathrm{C}(7)$ & $111 \cdot 1(9)$ & $\mathrm{N}(4)-\mathrm{C}(9)-\mathrm{C}(1)$ & $105 \cdot 5(10)$ \\
$\mathrm{Co}-\mathrm{N}(4)-\mathrm{C}(8)$ & $107 \cdot 0(7)$ & $\mathrm{N}(5)-\mathrm{C}(10)-\mathrm{C}(1)$ & $106 \cdot 4(9)$ \\
$\mathrm{Co}-\mathrm{N}(4)-\mathrm{C}(9)$ & $105 \cdot 4(7)$ & $\mathrm{N}(5)-\mathrm{C}(11)-\mathrm{C}(12)$ & $103 \cdot 4(9)$ \\
$\mathrm{C}(8)-\mathrm{N}(4)-\mathrm{C}(9)$ & $113 \cdot 7(9)$ & $\mathrm{N}(6)-\mathrm{C}(12)-\mathrm{C}(11)$ & $108 \cdot 1(9)$ \\
$\mathrm{Co}-\mathrm{N}(5)-\mathrm{C}(10)$ & $109 \cdot 5(7)$ & $\mathrm{N}(6)-\mathrm{C}(13)-\mathrm{C}(5)$ & $112 \cdot 5(9)$ \\
\hline & & & \\
& & &
\end{tabular}

Table 5. Torsion angles (degrees) for the rings involving the cobalt atom

\begin{tabular}{clcclr}
\hline Ring & \multicolumn{1}{c}{ Atoms } & Angle & Ring & \multicolumn{1}{c}{ Atoms } & Angle \\
\hline 1 & $\mathrm{Co}-\mathrm{N}(4)-\mathrm{C}(9)-\mathrm{C}(1)$ & $-23 \cdot 5(10)$ & 2 & $\mathrm{Co}-\mathrm{N}(1)-\mathrm{C}(1)-\mathrm{C}(10)$ & $55 \cdot 6(9)$ \\
& $\mathrm{N}(4)-\mathrm{C}(9)-\mathrm{C}(1)-\mathrm{N}(1)$ & $59 \cdot 4(11)$ & & $\mathrm{N}(1)-\mathrm{C}(1)-\mathrm{C}(10)-\mathrm{N}(5)$ & $-30 \cdot 6(12)$ \\
& $\mathrm{C}(9)-\mathrm{C}(1)-\mathrm{N}(1)-\mathrm{Co}$ & $-64 \cdot 4(9)$ & & $\mathrm{C}(1)-\mathrm{C}(10)-\mathrm{N}(5)-\mathrm{Co}$ & $-10 \cdot 7(10)$ \\
& $\mathrm{C}(1)-\mathrm{N}(1)-\mathrm{Co}-\mathrm{N}(4)$ & $39 \cdot 4(7)$ & & $\mathrm{C}(10)-\mathrm{N}(5)-\mathrm{Co}-\mathrm{N}(1)$ & $35 \cdot 4(7)$ \\
& $\mathrm{N}(1)-\mathrm{Co}-\mathrm{N}(4)-\mathrm{C}(9)$ & $-9 \cdot 7(7)$ & & $\mathrm{N}(5)-\mathrm{Co}-\mathrm{N}(1)-\mathrm{C}(1)$ & $-49 \cdot 2(7)$ \\
& & & & & \\
3 & $\mathrm{Co}-\mathrm{N}(4)-\mathrm{C}(8)-\mathrm{C}(7)$ & $-38 \cdot 9(10)$ & 4 & $\mathrm{Co}-\mathrm{N}(5)-\mathrm{C}(11)-\mathrm{C}(12)$ & $45 \cdot 6(9)$ \\
& $\mathrm{N}(4)-\mathrm{C}(8)-\mathrm{C}(7)-\mathrm{N}(3)$ & $46 \cdot 9(12)$ & & $\mathrm{N}(5)-\mathrm{C}(11)-\mathrm{C}(12)-\mathrm{N}(6)$ & $-52 \cdot 6(10)$ \\
& $\mathrm{C}(8)-\mathrm{C}(7)-\mathrm{N}(3)-\mathrm{Co}$ & $-33 \cdot 1(11)$ & & $\mathrm{C}(11)-\mathrm{C}(12)-\mathrm{N}(6)-\mathrm{Co}$ & $35 \cdot 6(10)$ \\
& $\mathrm{C}(7)-\mathrm{N}(3)-\mathrm{Co}-\mathrm{N}(4)$ & $9 \cdot 1(7)$ & & $\mathrm{C}(12)-\mathrm{N}(6)-\mathrm{Co}-\mathrm{N}(5)$ & $-7 \cdot 6(7)$ \\
& $\mathrm{N}(3)-\mathrm{Co}-\mathrm{N}(4)-\mathrm{C}(8)$ & $17 \cdot 1(7)$ & & $\mathrm{N}(6)-\mathrm{Co}-\mathrm{N}(5)-\mathrm{C}(11)$ & $-22 \cdot 3(7)$ \\
& & & & \\
5 & $\mathrm{Co}-\mathrm{N}(1)-\mathrm{C}(2)-\mathrm{C}(3)$ & $45 \cdot 9(10)$ & 6 & $\mathrm{Co}-\mathrm{N}(3)-\mathrm{C}(6)-\mathrm{C}(5)$ & $-36 \cdot 9(10)$ \\
& $\mathrm{N}(1)-\mathrm{C}(2)-\mathrm{C}(3)-\mathrm{N}(2)$ & $-52 \cdot 3(11)$ & & $\mathrm{N}(3)-\mathrm{C}(6)-\mathrm{C}(5)-\mathrm{C}(13)$ & $84 \cdot 7(11)$ \\
& $\mathrm{C}(2)-\mathrm{C}(3)-\mathrm{N}(2)-\mathrm{Co}$ & $34 \cdot 0(10)$ & & $\mathrm{C}(6)-\mathrm{C}(5)-\mathrm{C}(13)-\mathrm{N}(6)$ & $-46 \cdot 6(12)$ \\
& $\mathrm{C}(3)-\mathrm{N}(2)-\mathrm{Co}-\mathrm{N}(1)$ & $-6 \cdot 4(7)$ & & $\mathrm{C}(5)-\mathrm{C}(13)-\mathrm{N}(6)-\mathrm{Co}$ & $-23 \cdot 2(11)$ \\
& $\mathrm{N}(2)-\mathrm{Co}-\mathrm{N}(1)-\mathrm{C}(2)$ & $-22 \cdot 5(7)$ & & $\mathrm{C}(13)-\mathrm{N}(6)-\mathrm{Co}-\mathrm{N}(3)$ & $55 \cdot 3(8)$ \\
& & & $\mathrm{N}(6)-\mathrm{Co}-\mathrm{N}(3)-\mathrm{C}(6)$ & $22 \cdot 0(7)$ \\
\hline
\end{tabular}


complexes, i.e. where the 'en' $\mathrm{C}-\mathrm{C}$ axes are parallel or oblique to the pseudo- $C_{3}$ axis of the complex ion.

The coordination around the cobalt atom is a distorted octahedron composed of six nitrogen atoms. The principal distortion from octahedral symmetry is dictated by the form of the ligand framework. The least-squares plane involving atoms Co, $\mathrm{N}(2), \mathrm{N}(3), \mathrm{N}(4)$ and $\mathrm{N}(5)$ shows that they are not in the plane. The cobalt atom is shifted by $0.08 \AA$ towards $\mathrm{N}(6)$ from the least-squares plane through the four nitrogen atoms (supplementary material). The four nitrogens deviate $\pm 0.03 \AA$, alternately above and below the plane.

Two of the Co-N bond lengths are significantly different from the other four. Co-N $(4)$ is elongated $[2 \cdot 020(10) \AA]$ while the Co-N bond in the trans position is shortened $[\mathrm{Co}-\mathrm{N}(2) 1.933(10) \AA]$ as expected. However, the average Co-N length $(1.969 \AA)$ is typical for $\mathrm{Co}^{\mathrm{III}}-\mathrm{N}$ in saturated amine complexes. There are five five-membered chelate rings and four six-membered rings. The two five-membered rings in the cap possess an approximate envelope conformation, which is enforced by the stereochemistry of the cap. The distribution of the torsion angles within the six-membered chelate rings (Table 5) require twisted boat conformations, and again this is enforced by the cap geometries.

On the whole, all the $\mathrm{N}-\mathrm{Co}-\mathrm{N}$ angles deviate significantly from $90^{\circ}$. The angle $\mathrm{N}(3)-\mathrm{Co}-\mathrm{N}(6)$ which is part of a six-membered ring is enlarged $\left[96 \cdot 3(4)^{\circ}\right]$ whereas the angle opposite to it, $\mathrm{N}(1)-\mathrm{Co}-\mathrm{N}(5)$, is contracted $\left[83.0(4)^{\circ}\right]$. The other angles around the cobalt core vary between these two values. The deviations from octahedral geometry about the cobalt centre are very similar to those found in $\left[\mathrm{Co}\left(\mathrm{Cl}, \mathrm{CH}_{2} \mathrm{Cl}\right.\right.$-absar $\left.)\right]\left(\mathrm{NO}_{3}\right)_{3} \cdot{ }^{16}$

The crystal structure is stabilized by a network of hydrogen bonds $\mathrm{N}-\mathrm{H} \cdots \mathrm{Cl}$, $\mathrm{N}-\mathrm{H} \cdots \mathrm{O}$ (water), $\mathrm{O}-\mathrm{H} \cdots \mathrm{Cl}^{-}$and $\mathrm{O}-\mathrm{H}$ (water) $\ldots \mathrm{Cl}^{-}$with lengths: $\mathrm{N}(1)$ $\mathrm{H} \cdots \mathrm{O}\left(\mathrm{H}_{2} \mathrm{O}\right) \quad 3.081 \AA ; \mathrm{N}(2)-\mathrm{H} \cdots \mathrm{O}\left(\mathrm{H}_{2} \mathrm{O}\right) \quad 2.957 \AA ; \mathrm{N}(3)-\mathrm{H} \cdots \mathrm{Cl}(2) \quad 3.19 \AA ;$ $\mathrm{N}(4)-\mathrm{H} \ldots \mathrm{Cl}(1) \quad 3.18 \AA ; \mathrm{N}(5)-\mathrm{H} \ldots \mathrm{Cl}(3) \quad 3.106 \AA ; \mathrm{N}(6)-\mathrm{H} \ldots \mathrm{Cl}(1) \quad 3.066 \AA ;$

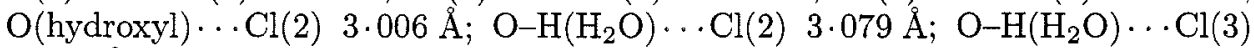
$2.978 \AA$. These interactions are normal for such amine complex cations and associated anions.

\section{Spectral and Electrochemical Properties of the Complexes}

Table 1 lists the relevant spectroscopic properties and reduction potentials. The electronic spectra of $[\mathrm{Co}(\mathrm{Me}, \mathrm{OH} \text {-absar })]^{3+}$ and $[\mathrm{Co}(\mathrm{Me}, \mathrm{OH}-\mathrm{sar})]^{3+}$, which differ only in the absence or presence of an additional methylene unit in the cap (corresponding to the regular 'sar' cavity) are shown in Fig. 3. The hypsochromic shift of the band maxima from $\left[\lambda_{\max }\right.$ in $\mathrm{nm}\left(\epsilon_{\max }\right.$ in $\mathrm{dm}^{3} \mathrm{~mol}^{-1}$ $\left.\mathrm{cm}^{-1}\right)$ ] $472(143)$ and 344 (124) in [Co(Me,OH-sar)] $]^{3+}$ to 458 (175) and 336 (172) in $[\mathrm{Co}(\mathrm{Me}, \mathrm{OH} \text {-absar })]^{3+}$ is consistent with an increased ligand field strength in the contracted cage complex. A modest increase in the molar absorption coefficient $(\epsilon)$ is consistent with the loss of symmetry between the 'sar' and the 'absar' based cages and the increased probability of mixing with ungerade electronic states to make the transition more allowed. ${ }^{22}$ The spectra of the corresponding cobalt(II) complexes are shown in Fig. 4, together with that of

${ }^{22}$ For example, Figgis, B. N., in 'Comprehensive Coordination Chemistry' (Ed. G. Wilkinson) Vol. 1 (Pergamon: Oxford 1987). 
$[\mathrm{Co}(\mathrm{sep})]^{2+}$ (sep $=1,3,6,8,10,13,16,19$-octaazabicyclo[6.6.6]icosane) for comparison. The spectrum of the contracted cage species $[\mathrm{Co}(\mathrm{Me}, \mathrm{OH}-\mathrm{absar})]^{2+}$ is reminiscent of that reported for $[\mathrm{Co}(\mathrm{Me} \text {-azasar })]^{2+},{ }^{23}$ and $[\mathrm{Co}(\mathrm{sep})]^{2+},{ }^{24}$ in contrast to that

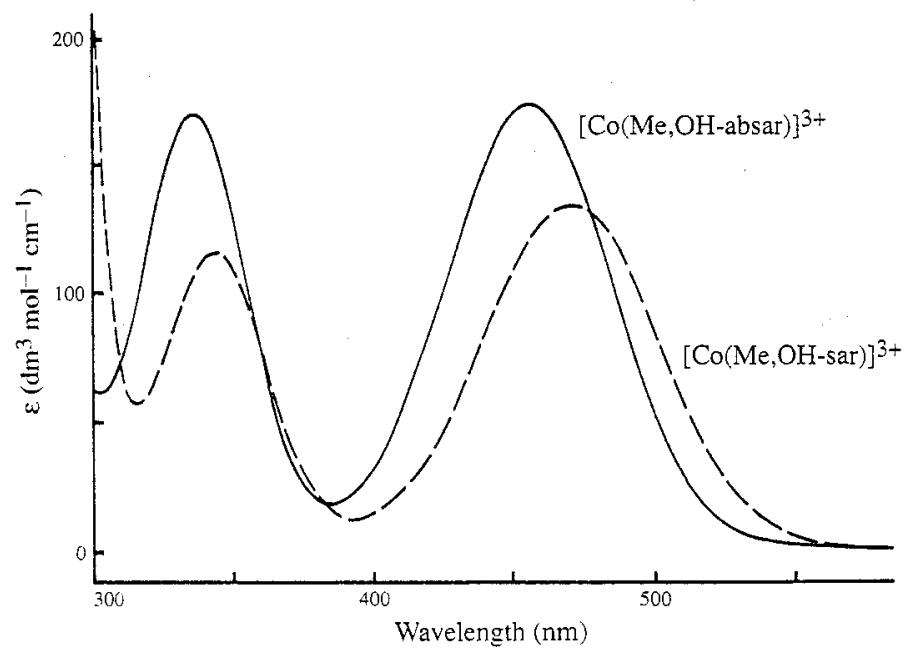

Fig. 3. Electronic spectra of $[\mathrm{Co}(\mathrm{Me}, \mathrm{OH}-\mathrm{sar})]^{3+}$ and $[\mathrm{Co}(\mathrm{Me}, \mathrm{OH}-\mathrm{absar})]^{3+}$ in $\mathrm{H}_{2} \mathrm{O}$.

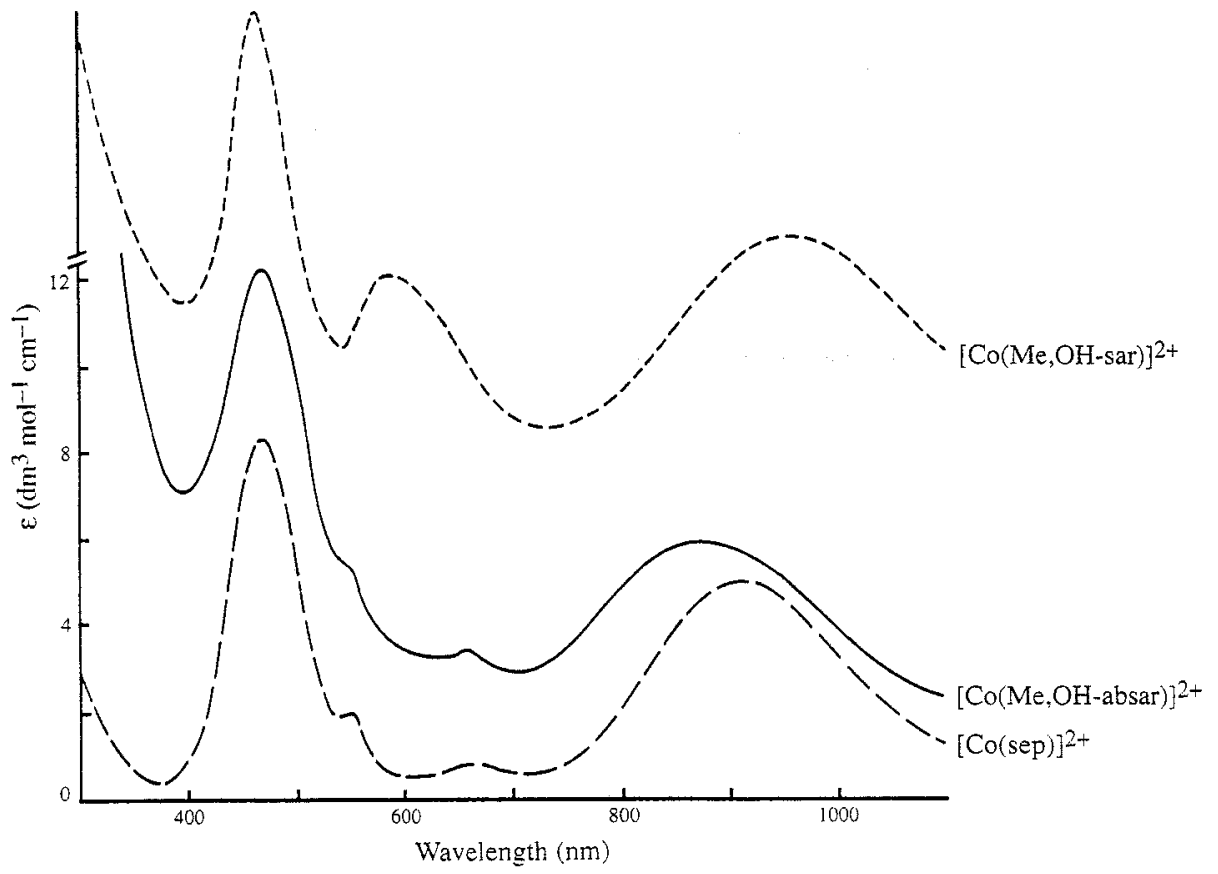

Fig. 4. Electronic spectra of $[\mathrm{Co}(\mathrm{Me}, \mathrm{OH}-\mathrm{sar})]^{2+},[\mathrm{Co}(\mathrm{Me}, \mathrm{OH}-\mathrm{absar})]^{2+}$ and $[\mathrm{Co}(\mathrm{sep})]^{2+}$ in $\mathrm{H}_{2} \mathrm{O}$. The spectrum of $[\mathrm{Co}(\mathrm{Me}, \mathrm{OH}-\mathrm{sar})]^{2+}$ has been displaced $(\epsilon+6)$ for clarity.

${ }^{23}$ Creaser, I. I., Geue, R. J., Harrowfield, J. M., Herlt, A. J., Sargeson, A. M., Snow, M. R., and Springborg, J., J. Am. Chem. Soc., 1982, 104, 6016.

${ }^{24}$ Creaser, I. I., Harrowfield, J. M., Herlt, A. J., Sargeson, A. M., Snow, M. R., Springborg, J., Geue, R. J., and Snow, M. R., J. Am. Chem. Soc., 1977, 99, 3181. 
of $[\mathrm{Co}(\mathrm{Me}, \mathrm{OH}-\mathrm{sar})]^{2+}$ which has a similar peak pattern but significantly shifted peak positions. It is evident, however, that the $\mathrm{Co}^{\mathrm{II}}$-absar complex is a high-spin molecule like the $\mathrm{Co}^{\mathrm{II}}$-sar type complexes despite the contracted cage engineered by the extrusion of a methylene group.

The fact that the contracted absar cage has a smaller preferred cavity for cobalt(II) than the sar cages is also apparent from the reduction potentials. The potential of the $[\mathrm{Co}(\mathrm{Me}, \mathrm{OH}-\mathrm{sar})]^{3+/ 2+}$ couple is $-385 \mathrm{mV}$ (v. s.h.e. in $0.2 \mathrm{M}$ $\mathrm{KCl})$, whereas that of the $[\mathrm{Co}(\mathrm{Me}, \mathrm{OH} \text {-absar })]^{3+/ 2+}$ couple is $-551 \mathrm{mV}$, reflecting the significantly increased strain accompanying the reduction of the cobalt(III) centre in the smaller 'absar' cage. The reduction potential of the ruptured cage (5) $\left[\mathrm{Co}\left(6-\mathrm{Me}, 13-\mathrm{NO}_{2}, 6-\mathrm{CH}_{2} \mathrm{NHCH}_{2} \mathrm{CH}_{2} \mathrm{NH}_{2}-[14] \mathrm{aneN}_{4}\right)\right]^{3+}$ is the same for both isomers $(-196 \mathrm{mV})$, and only marginally more positive than that of the parent complex $\left[\mathrm{Co}\left(\mathrm{Me}, \mathrm{NO}_{2} \text {-sar }\right)\right]^{3+}(-264 \mathrm{mV})$.

\section{Summary}

This paper essentially describes a new method of contracting the 'sar' type cage to give such products in relatively high yield. The new molecule has a stronger ligand field than the parent, and, as it accommodates the cobalt(III) ion better than the cobalt(II) ion, it destabilizes the latter oxidation state. The reaction process represents a ready route to modulating the electronic properties of the cage complexes by altering the cavity size.

\section{Acknowledgment}

We thank the Australian National University Microanalytical Services Unit for analyses. 